\title{
Hong Kong SAR Economic Integration with the Pearl River Delta
}

\author{
Hongyi Chen and Olaf Unteroberdoerster
}





\title{
IMF Working Paper
}

Asia and Pacific Department

Hong Kong SAR Economic Integration with the Pearl River Delta

\author{
Prepared by Hongyi Chen and Olaf Unteroberdoerster ${ }^{1}$
}

Authorized for distribution by Nigel Chalk

December 2008

\begin{abstract}

\section{This Working Paper should not be reported as representing the views of the IMF.} The views expressed in this Working Paper are those of the author(s) and do not necessarily represent those of the IMF or IMF policy. Working Papers describe research in progress by the author(s) and are published to elicit comments and to further debate.
\end{abstract}

Hong Kong SAR's economic integration with the Mainland has primarily taken place in the Pearl River Delta (PRD). Taking stock of integration trends, this paper discusses key implications for ensuring economic benefits of further integration are sustained and associated costs minimized. Besides further investments in infrastructure, Hong Kong SAR's role as a producers services and finance hub will depend on frictionless movements of goods, services, people and know-how, requiring policy coordination to further promote trade and investment and developing a common human skills base with the PRD. Regional cooperation will also be needed to minimize the costs of rising levels of cross-border pollution.

JEL Classification Numbers:F15, F23, F36

Keywords: Economic integration, trade, investment, producer services, financial integration, global supply-chain management, cross-border pollution

Author's E-Mail Address: hchen2@imf.org; ounteroberdoerster@imf.org

\footnotetext{
${ }^{1}$ We are grateful for helpful comments at a seminar at the Hong Kong Monetary Authority (HKMA) and from colleagues in the IMF Hong Kong SAR team.
} 


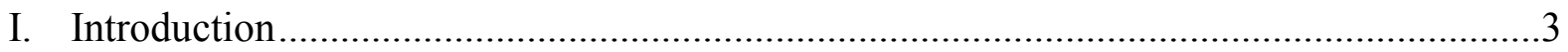

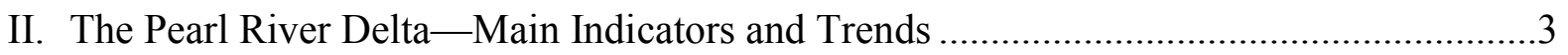

III. Hong Kong SAR and the Pearl River Delta —Changing Economic Linkages ....................8

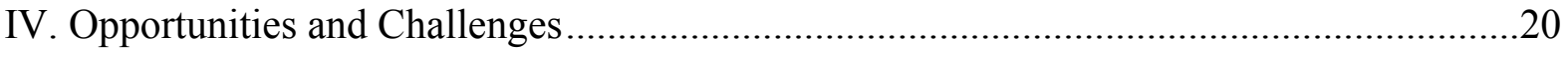

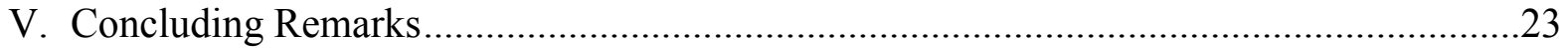

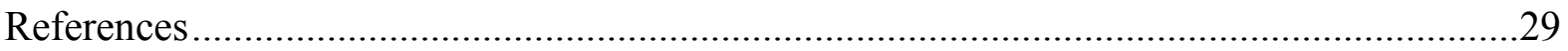

Boxes

1. Pearl River Delta: The Role of Clusters in the Economic Development.............................6

2. Firm-Level Trade Links Between Hong Kong SAR and the PRD ..................................13

3. Hong Kong as a Producer and Trading Services Hub: Li\&Fung Ltd..............................14

4. The Integrative Role of the Closer Economic Partnership Agreement (CEPA).................15

Figures

1. Distribution of Activity Across PRD in 2006 ...............................................................

2. Pearl River Delta Cities and Hong Kong SAR: Selected Economic Indicators in 2006 .....7

3. Connectivity: FDI and Distance from Hong Kong SAR …….......................................

4. Connectivity: FDI, Output, Exports, and Growth......................................................10

5. Monthly Average Air Pollution Levels in PRD and Hong Kong SAR, 2006 ....................18

Tables

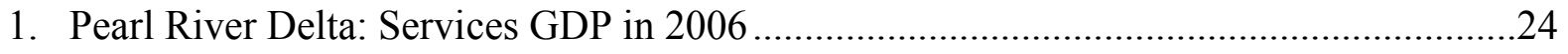

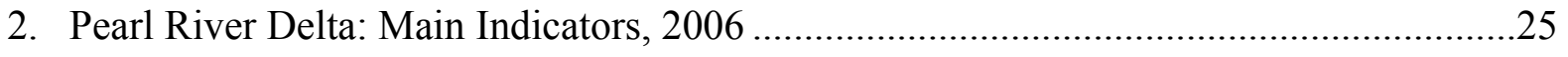

3. Foreign Direct Investment (FDI) in Guangdong, 1979-2006 ........................................26

4. Pearl River Delta: Foreign Direct Investment (FDI), 1996-2006 ...................................26

5. Choice of Location for Various Business Activities..........................................................2

6. Role of Hong Kong SAR in Pearl River Delta Export Performance .................................28 


\section{INTRODUCTION}

Hong Kong SAR's integration with the Mainland - essential for the city's transformation to a finance- and service-based economy - has primarily taken place in the Pearl River Delta (PRD). Between 2001 and 2006, the stock of Hong Kong SAR's outward FDI into the Mainland nearly tripled to US\$270 billion and accounted for almost 80 percent of all outward FDI. The PRD is estimated to capture some 40 percent of this investment. Guangdong provincial statistics indicate that over 70 percent of all FDI agreements signed between 1979 and 2006 are with Hong Kong SAR companies. Roughly, two-thirds of all Hong Kong SAR imports from the Mainland are sourced from Guangdong province. Since its opening in 1979, the PRD economic zone has become the industrial hinterland, allowing Hong Kong SAR to shift factories across the border, tap relatively cheap industrial labor, and to leverage its advantage in logistics and other producer services and finance.

As an integrated whole, the greater PRD economy is amongst the largest in the world. As a result of three decades of economic integration and intra-regional specialization, the economies of the greater Pearl River Delta, comprising Hong Kong SAR, Macao SAR, and the PRD economic zone in Guangdong Province, produce goods and services well in excess of US\$500 billion a year, which would place them easily into the top 20 largest economies worldwide. Yet, with a combined population of about 100 million and average per capita GDP at market prices in 2006 of about US\$6,000, compared with Hong Kong SAR's US\$27,000, there is significant potential for further development and growth on both sides.

This paper aims first to take stock of integration trends, and then to outline key implications for ensuring economic benefits from further integration are sustained and associated risks minimized. Specifically, cities in the PRD closest to Hong Kong SAR have been the primary beneficiaries of investment and income growth. At the same time, given extensive trade and investment links, structural change and shocks in the PRD economy have direct repercussions for growth, trade, corporate profitability, and increasingly financial sector performance in Hong Kong SAR. Moreover, industrialization causing rising levels of transboundary pollution has become a threat to Hong Kong SAR's competitiveness as an international financial center. All this calls for greater policy coordination between Hong Kong SAR and the PRD in terms of structural reform (including the investment and trade regime, and education), future infrastructure development to enhance connectivity and environmental policy.

\section{The Pearl River Delta-Main Indicators ANd TrendS}

The PRD economic zone is commonly defined to comprise nine cities around the Pearl River Delta in Guangdong province (Enright and others, 2005): Guangzhou (the capital of Guangdong province), Shenzhen, Foshan, Zhuhai, Jiangmen, Zhongshan, Dongguan, four 
districts and counties of Huizhou and four districts and counties of Zhaoqing. Shenzhen, Dongguan and Huizhou are on the east side of the Pearl River and form the Eastern PRD; Guangzhou is the Central PRD; the rest form the Western PRD. Together with Hong Kong SAR and Macao SAR, the nine cities are often referred to as the greater PRD.

Since the beginning of China's opening and reform policy in 1979, Guangdong province

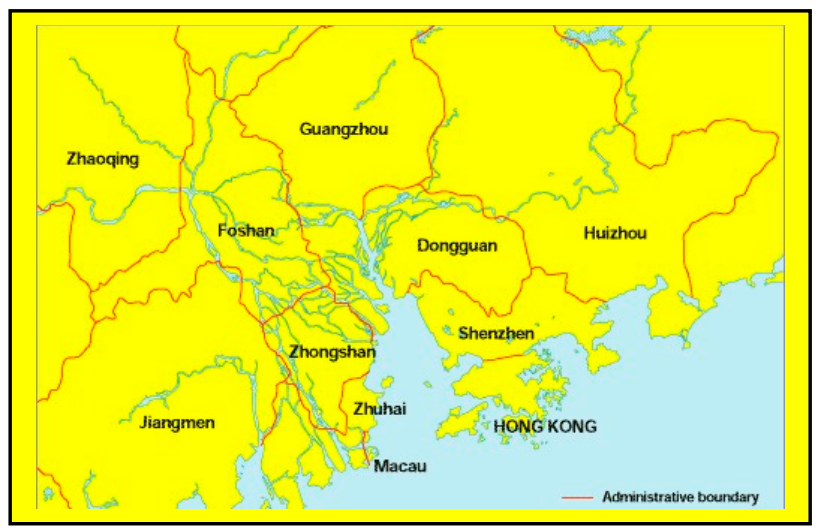
and at its core the PRD have experienced rapid economic change and development. In 2006, the PRD's per capita GDP was three times of the national average and with only 3.3 percent of China's total population, the region accounted for about 10 percent of the nation's output. While industrialization has been the initial driver of growth, the share of services in output has increased in recent years, in particular in Guangzhou, the provincial capital, and Shenzhen, the city neighboring Hong Kong, where services now account for more than one third of output (Table 1). In logistics, Shenzhen is now the fourth largest container port in the world and multinational companies, such as Aeon, IBM and Wal-Mart, have set up global or regional sourcing centers there. In part reflecting its immediate vicinity to Hong Kong, Shenzhen also has the highest concentration of financial services in the PRD region and hosts the mainland's second stock exchange. At the same time, Guangzhou has become one of the leading trade fair centers in China, hosting 651 exhibitions in $2006 .^{2}$
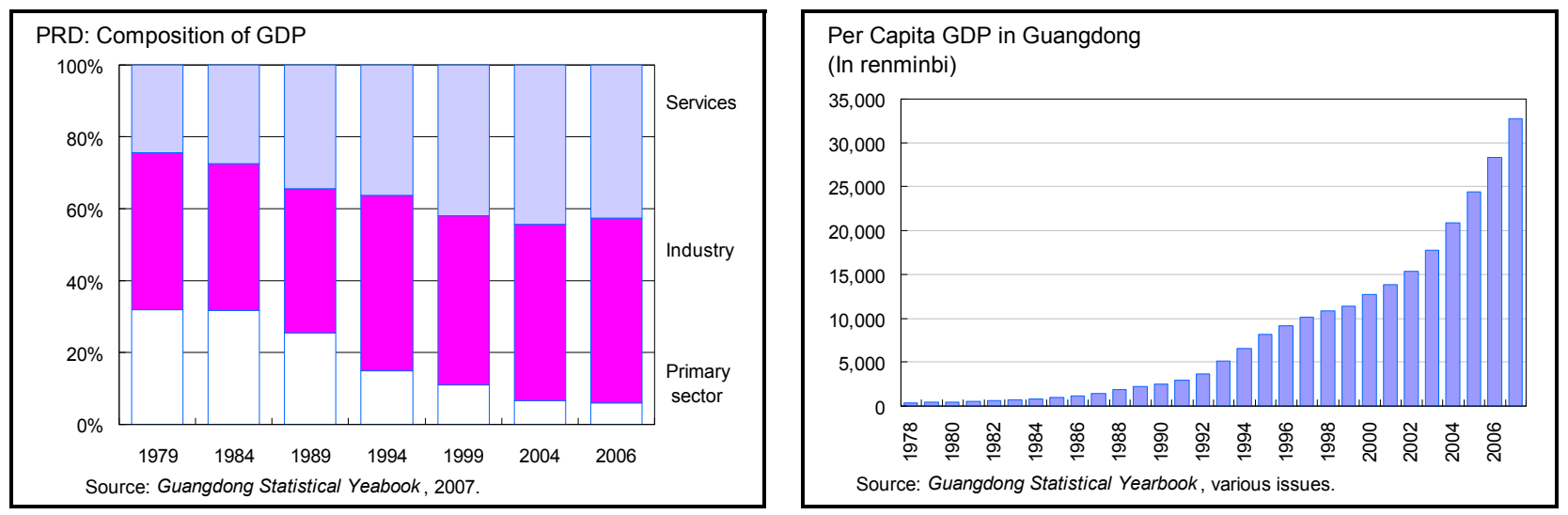

\footnotetext{
${ }^{2}$ Moreover, Guangzhou's $11^{\text {th }}$ Five-Year Program (2006-2010) lists financial, logistics, product design and packaging, legal, accounting and information services as priority development targets in business services. All these areas are open to foreign companies.
} 
A key characteristic of growth in the PRD has been the emergence of industry and services clusters. While the Eastern PRD focuses on electronics and IT products, the Western PRD has a relatively high weight in household appliances (Box 1). Firms in these clusters can draw upon common skills bases or inputs and reinforce each others' competitive positions through dynamic interaction (Enright and others, 2005). Specifically, the emergence of clusters has allowed regions in the PRD to consolidate downstream and upstream industries and deepen their specialization, thereby reacting faster to changes in demand and reducing costs. The network externalities created in clusters also imply that locational choice of firms in the PRD is less and less determined on the basis of simple cost comparisons of individual factors of production (see Sections III and IV).

Yet, despite impressive growth for the PRD region as a whole, there are marked differences in economic activity across the municipalities. The two largest by registered population, Guangzhou and Shenzhen, representing about 23 percent and 16 percent, respectively, of the total population in the PRD, account for nearly two-thirds of the region's output (Table 2 and Figure 1). Nearly half of all exports originate in Shenzhen, which is also a leader in industry. Most of foreign direct investment, nearly half, also goes into the two cities. By contrast, five other municipalities each account for only 5 percent or less of the region's output, exports, or inward foreign direct investment.

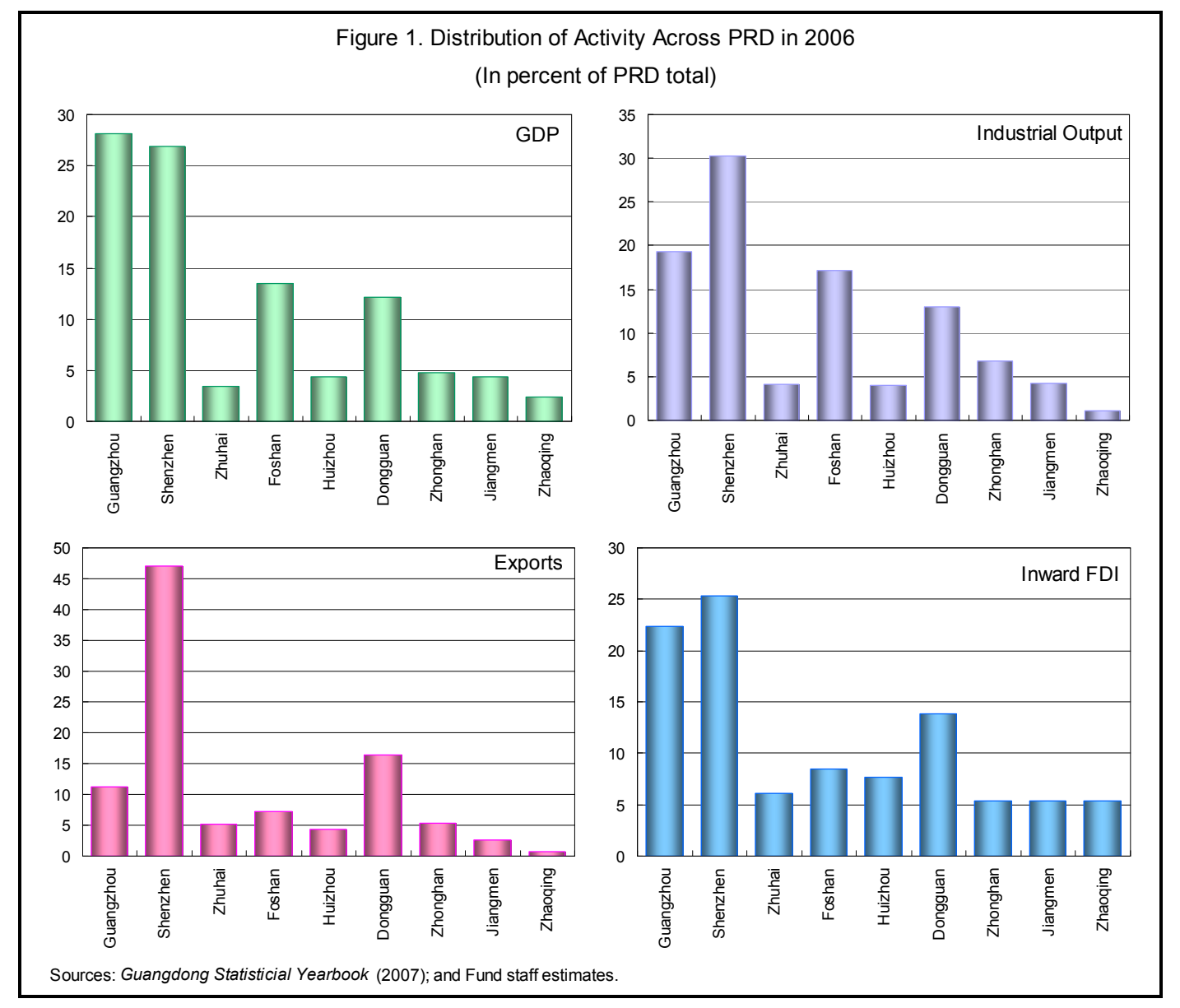




\section{Box 1. Pearl River Delta: The Role of Clusters in the Economic Development}

Industry and services clusters have become an important development feature across the municipalities of the PRD. A number of higher value-added industries are concentrated in Guangzhou (autos, transportation equipment), and Shenzhen (electronics), which are the largest recipients of foreign direct investment in the PRD. Variations in the concentration of certain industries across different cities are also closely related to their economic performance, notably differences in per capita income.

Recent large-scale investments in clusters include the auto, high tech, and chemical industries.

- For example, Guangzhou is becoming one of the three auto manufacturing bases in China, with a capacity of over half a million cars in 2006. A plant set up by Honda in 1998 initiated the autos and parts cluster in Guangzhou, joined later by Nissan and Toyota, and light truck specialist Hyundai. Auto parts manufacturers have also been locating in nearby areas, with

\begin{tabular}{|c|c|}
\hline \multicolumn{2}{|r|}{ Pearl River Delta: Industry Clusters } \\
\hline City & Clusters \\
\hline Guangzhou & $\begin{array}{l}\text { Autos and parts, transport equipment, electrical products, } \\
\text { electronics, chemicals, garments, textiles, business services, } \\
\text { software, toys }\end{array}$ \\
\hline Panyu $1 /$ & $\begin{array}{l}\text { Sports goods, textiles, garments, jewellery, toys, electric supply } \\
\text { equipment, shipping containers }\end{array}$ \\
\hline Shenzhen & $\begin{array}{l}\text { Electronics, computer products, telecom products, ICs, toys, } \\
\text { plastics, watches, clocks, oil paintings, port services, logistics, } \\
\text { finance, printing, artificial trees }\end{array}$ \\
\hline Dongguan & $\begin{array}{l}\text { Electronics computers, components, peripherals, garments, } \\
\text { furniture, shoes, toys, watches, clocks, cutlery, kitchen tools, } \\
\text { soldering machinery, angling equipment }\end{array}$ \\
\hline Huizhou & $\begin{array}{l}\text { Laser diodes, digital electronics, CD-ROMs, telephones, batteries, } \\
\text { circuit boards, precision machinery, plastics, chemicals }\end{array}$ \\
\hline Zhongshan & $\begin{array}{l}\text { Lighting fixtures, lamps, metal products, motorcycles, casual } \\
\text { wear, locks, audio equipment }\end{array}$ \\
\hline Foshan & $\begin{array}{l}\text { Industrial ceramics, ceramic artwork, needlework, textiles, } \\
\text { children's garments }\end{array}$ \\
\hline Chencun $1 /$ & Flower farming, ornamental fish, turf farming \\
\hline Nanhai 1/ & Textiles, aluminum products, motorcycles, underwear \\
\hline Shunde $1 /$ & $\begin{array}{l}\text { Electrical appliances, woodworking, shipping containers, furniture, } \\
\text { machinery, bicycles }\end{array}$ \\
\hline Jiangmen & Textiles, garments, paper, batteries \\
\hline \multicolumn{2}{|c|}{ Source: Enright, Scott, and Chang, 2005.} \\
\hline \multicolumn{2}{|c|}{$\begin{array}{l}\text { 1/ Panyu is a district of Guangzhou. Chencun, Nanhai and Shunde are districts of } \\
\text { Foshan. }\end{array}$} \\
\hline
\end{tabular}
around 450 auto and auto parts manufacturers having set up factories in Guangdong and surrounding cities establishing special development zones e.g., in Foshan, Zhongshan, Shenzhen and Huizhou's Daya Bay.

- A prominent high tech cluster is Nanshan (Shenzhen) where electronics and other high tech goods made up 50 percent of total output in 2003. The area has attracted leading foreign firms, such as IBM, Compaq, and Oracle, as well as local companies, such as Huawei and Zhongxing.

- Another example of recent cluster growth is the petrochemical industry. Construction work in Guangzhou Royal Dutch Shell, a US\$4.3 billion petrochemicals complex jointly set up by CNOOC (China National Offshore Oil Corp.) and Shell Petrochemicals Company Ltd., has just been finished at Daya Bay in Huizhou. Once completed, the JV company will produce about 2.3 million tons per year. In addition, five oil-refining plants, five petrochemical plants and five ethylene plants are listed in the "Plan of 9 Industries in Guangdong Province during 2006-2010." 
At the same time, key development indicators still vary greatly within the PRD, but also between the PRD and Hong Kong SAR. With per capita GDP at more than 1.6 times the regional average, average income in Shenzhen is five times higher than in Zhaoqing, the poorest municipality in the PRD. ${ }^{3}$ The difference between these two cities is even more pronounced when it comes to exports per capita (36 times). Regarding foreign direct investment, differences are less pronounced in per capita terms, but at nearly 4:1 (between

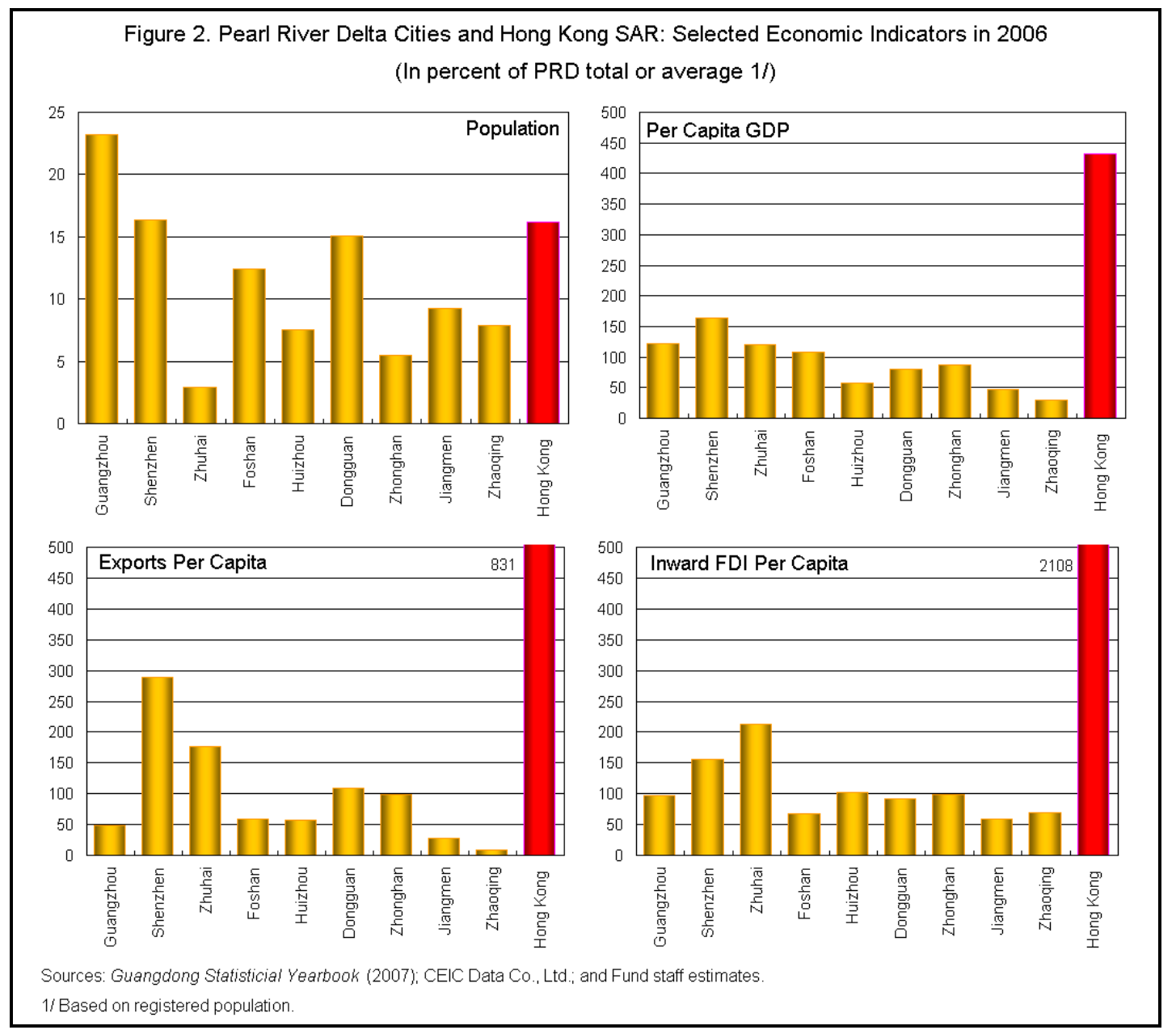

Zhuhai and Jiangmen) are still large. However, when compared with Hong Kong SAR, even the most advanced municipalities in the PRD lag significantly behind, including in terms of per capita income (2.6:1), per capita exports (2.8:1), and per capita FDI (9.9:1), with the latter largely reflecting Hong Kong's status as an international financial center. These differences suggests that further integration between Hong Kong SAR and the PRD still offers significant development potential, both within the PRD, but also for Hong Kong SAR and the PRD as a whole. At the same time, the threat that the PRD becomes a direct

\footnotetext{
${ }^{3}$ Per capita estimates are based on registered population. To the extent that this does not capture migrants who are concentrated in the more advanced economic centers of the PRD, per capita estimates would tend to overstate differences within the PRD and understate differences between the PRD and Hong Kong SAR.
} 
competitor for Hong Kong SAR appears remote, at least over the medium term. The economic linkages and their evolving nature are discussed in the next section.

\section{Hong Kong SAR and the Pearl River Delta-Changing ECONOMIC LINKAGES}

\section{Connectivity: The Infrastructure Dimension}

Connectivity has been a key determinant of deepening integration, spurring investment and growth in those parts of the PRD closest to Hong Kong. There is a negative relationship between both, the number of Hong Kong enterprises in various PRD municipalities and the share of those municipalities in total foreign investment, and their distance to Hong Kong (Figure 3$){ }^{4}$ The cities in the PRD closer to Hong Kong clearly have an advantage in attracting investment, both from overseas and Hong Kong, especially cities in the eastern part of PRD that have land access to Hong Kong, such as Shenzhen and Dongguan. The only direct access to Western part of PRD is through ferry and cargo ship, which is relatively time-consuming and costly for cross-border transportation of goods and raw materials. ${ }^{5}$

With foreign direct investment, higher industry value-added, higher exports, higher economic growth, and higher per capita GDP have followed (Figure 4). The result has been faster development in the eastern part of the PRD. In 1980, when Guangdong started its economic reform and opened up, the share of GDP of the eastern PRD in the region's total GDP was only 14 percent. Two and a half decades later, the eastern PRD, which has easier access to Hong Kong, accounts for 45 percent of the

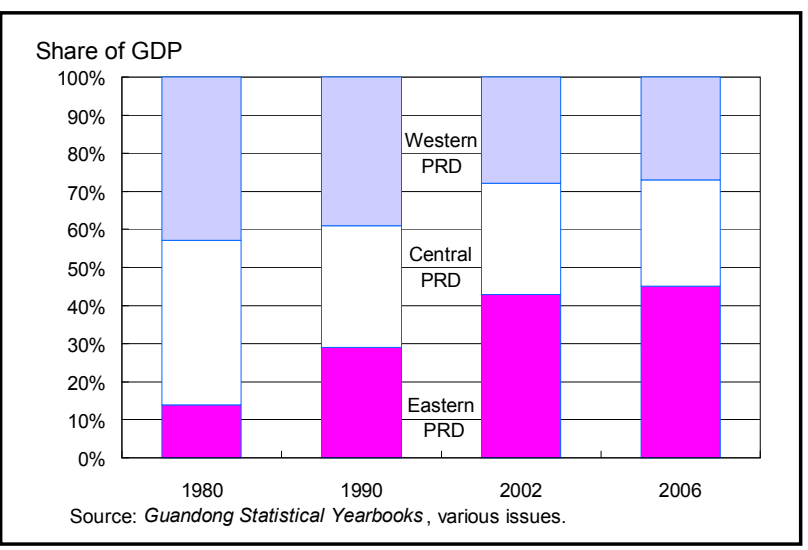
total GDP in the PRD.

\section{Investment, Trade and Services: The Common Market Dimension}

The growing interdependency between Hong Kong SAR and the PRD is reflected particularly in investment and trade flows. Hong Kong is by far the single largest source of foreign direct investment in the PRD and the PRD is the most important destination of

\footnotetext{
${ }^{4}$ The result also holds for average travel time, instead of distance, using data from Enright and Scott (2006).

${ }^{5}$ Easier access to Hong Kong is certainly an important factor for Hong Kong and overseas investors, but other factors also play a role. In particular, Guangzhou, as the capital city of Guangdong province, may have received a larger share of investment because of its traditional importance and advantages (.e.g., infrastructure, supply of skilled labor) in the Guangdong economy. If Guangzhou is taken out as an outliner, the negative relationship between share of FDI and distance from Hong Kong is even stronger.
} 
Figure 3. Connectivity: FDI and Distance from Hong Kong SAR

Share of FDI (1996-2006) versus Distance from Hong Kong SAR

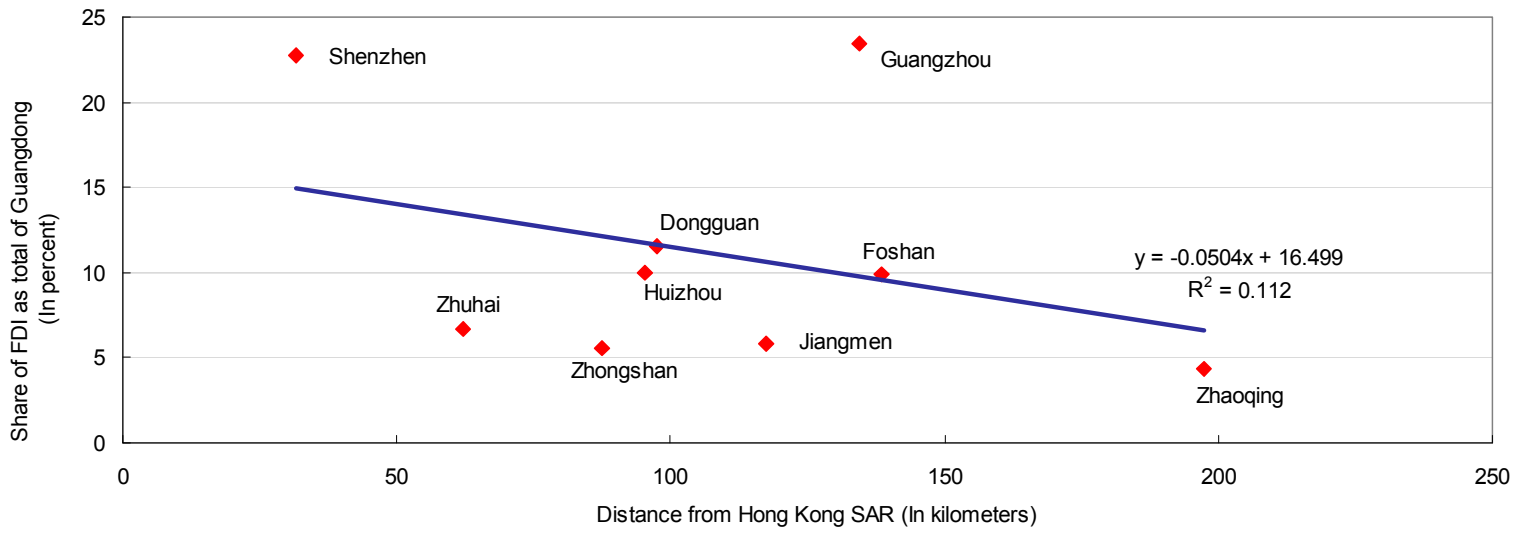

Share of FDI (1996-2006) versus Distance from Hong Kong SAR (excluding Guangzhow)

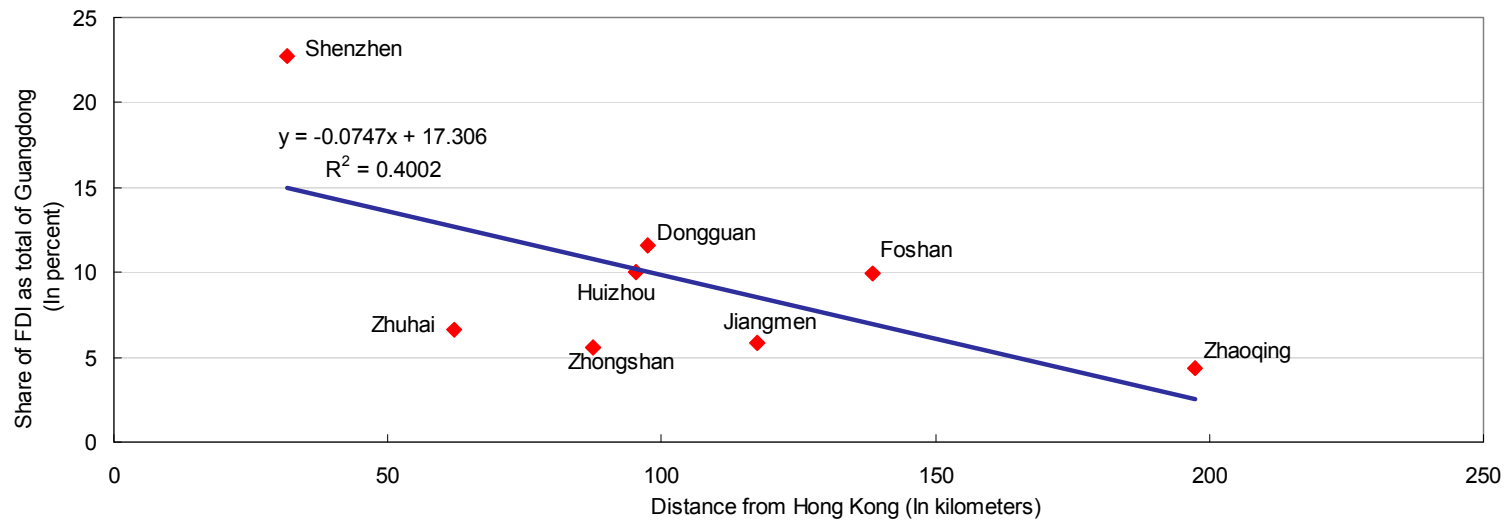

Number of Hong Kong Enterprises (2006) versus Distance from Hong Kong SAR

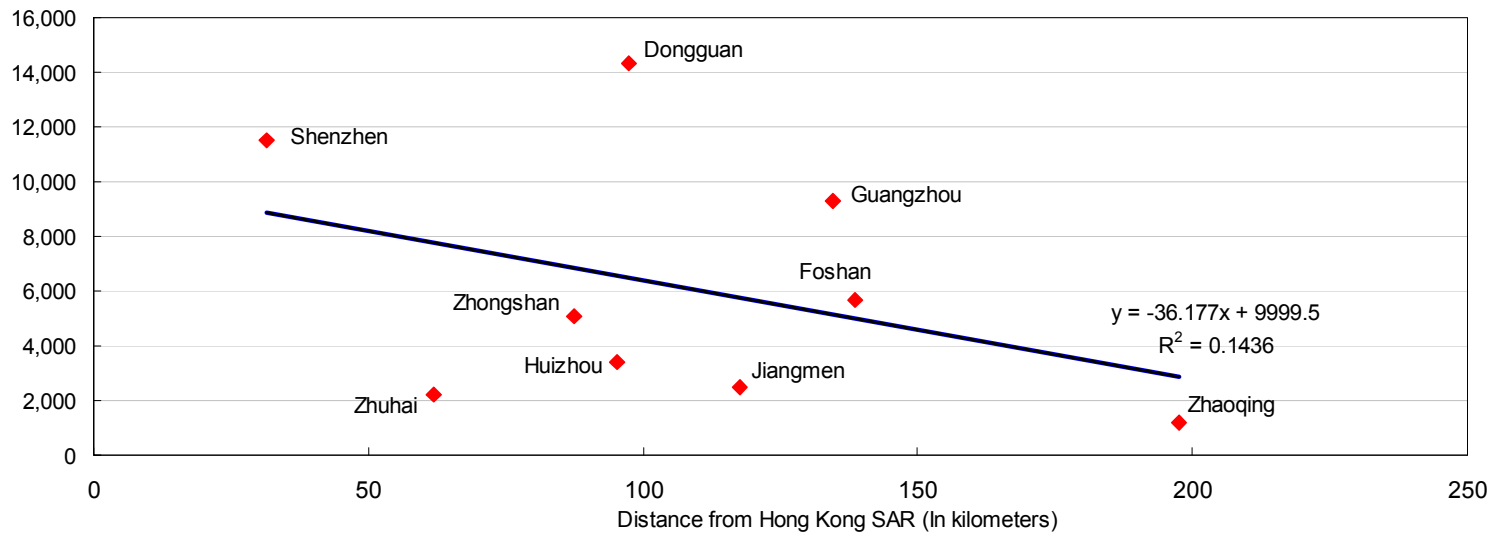


outward direct investment from Hong Kong. According to Guangdong provincial statistics, during the period of 1979-2006, Hong Kong companies signed 92,532 investment contracts with utilized capital amounting to US\$112.2 billion, or 63.2 percent of Guangdong's total foreign investment (Table 3). The PRD is estimated to account for the major part of Hong Kong's FDI, as it captures more than 90 percent of utilized FDI in Guangdong (Table 4). Matching these data with Hong Kong statistics, which do not provide a detailed breakdown of outward FDI according to provinces, suggests that direct investment in Guangdong accounts for 41.3 percent of Hong Kong's total outward investment in the Mainland. ${ }^{6}$

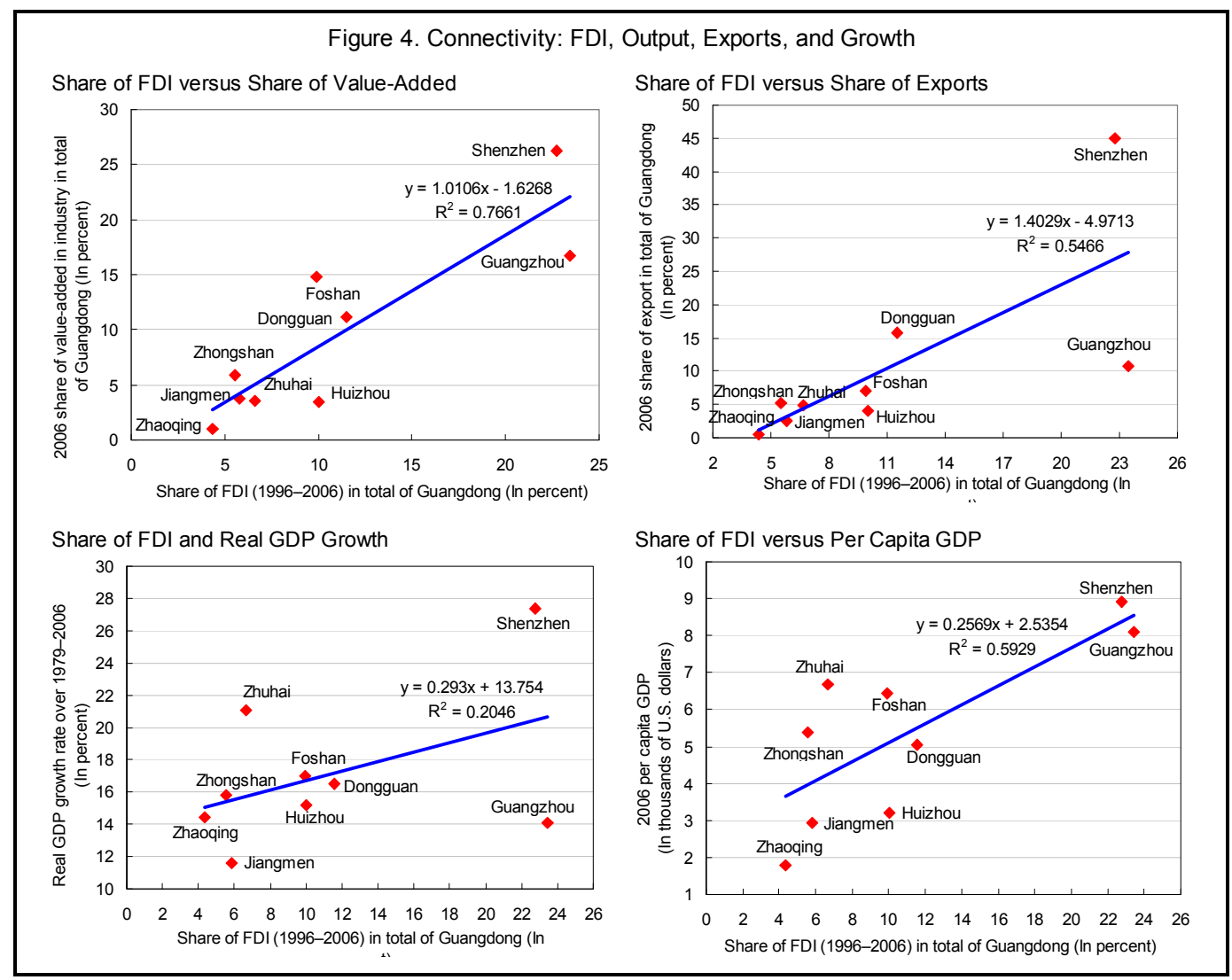

Hong Kong-based firms account for the bulk of foreign-invested enterprises in the PRD. The investment comes mainly in two forms: foreign-invested enterprises (FIEs), ${ }^{7}$ and other contractual forms (OCFs), which are mainly in processing trade. According to a 2007 enterprise survey by the Federation of Hong Kong Industries, henceforth referred to as the FHKI survey, Hong Kong-funded enterprises and Hong Kong enterprises in OCFs approximately accounted for 55,200 manufacturing enterprises and 57,500 factories in the

${ }^{6}$ According to Hong Kong statistics, by the end of 2006, the total stock of foreign direct investment in the Mainland was about US\$271.4 billion, about 80 percent of the SAR's total outward FDI.

${ }^{7}$ Including wholly foreign-funded enterprises, equity joint ventures and cooperative joint ventures with the foreign partner having a statutory controlling stake. 
PRD,${ }^{8}$ representing some 89 percent of all foreign invested enterprises. More than 50 percent of these enterprises are in the Eastern PRD, in particular in Shenzhen and Dongguan, reflecting again the greater connectivity with these municipalities. While Hong Kong enterprises in the PRD engage in a wide range of industries, the bulk of them, 82 percent, are operating in Original Equipment Manufacturing (OEM), meaning they have been identified by overseas buyers as suppliers and engage in production and delivery according to the design and specifications provided to them by Hong Kong based supply-chain managers such as Li\&Fung Ltd. (see below). By contrast, only 13 percent of enterprises are directly engaged in building and developing their own brand-Original Brand Manufacturing (OBM).

Firm relationships have been evolving to a more symmetric division of labor in management and administration. As reflected in the declining share of enterprises of recent vintages, the mode of engagement of Hong Kong-based enterprises in the PRD has changed from a Hong Kong-dominated mode to a more cooperative one, where the traditional model, coined "a shop in the front and a factory in the back" has been evolving to a more complex and symmetric division of labor. In the early years of opening of the PRD, Hong Kong companies came in to build factories to take advantage of cheap labor, low land and raw material costs, and low environmental regulation.

Administrative services, including financial management, sales and marketing, import and export were left in Hong Kong. With the development of the PRD and improving business environment, mainly reflecting the deepening of the supply chain networks and clusters in the PRD, and the availability of skilled labor, Hong Kong companies were able to move increasingly higher valued-added business service activities to the PRD. According to the FHKI survey, the shift in business service activities from Hong Kong

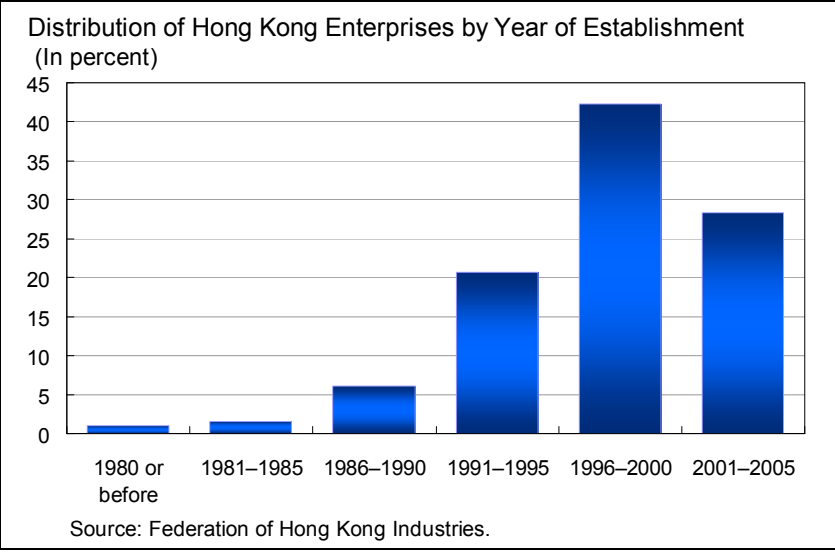

Share of Firms with Acitivities in Both Hong Kong SAR and PRD (In percent)

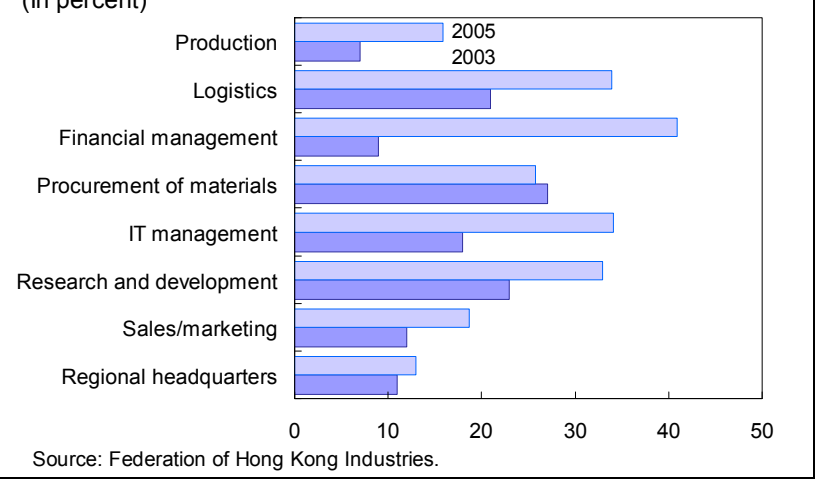
SAR to the PRD has been particularly strong in the areas of IT management, financial management, and sales and marketing (Table 5). The result is a more broad-based division of labor relying on more intensive interaction across all types of business activities. From headquarter functions, to research and

\footnotetext{
${ }^{8}$ Since the number of enterprises and the number of factories are similar, in the following analysis, only the number of enterprises are analyzed.
} 
development, to production, the share of firms undertaking such activities in both Hong Kong and the PRD has risen in recent years.

The focus of investments in processing trade and OEM has been a key force in generating close bilateral trade links between the PRD and Hong Kong (Table 6). As a major export base for Mainland China, accounting for nearly one third of all Mainland exports, the PRD is also the most important source of Mainland imports for Hong Kong. Exports from PRD have accounted for about 95 percent of total exports from Guangdong in recent years, and about 70 percent of PRD exports were in processing trade. More than a third of Guangdong's exports were through Hong Kong, a number that has remained relatively steady in recent years, suggesting that Hong Kong's role in bringing PRD goods to the world market has not diminished. However, Guangdong's share in Hong Kong's mainland imports has doubled from 34 percent in 2000 to 70 percent in 2006. This reflects a

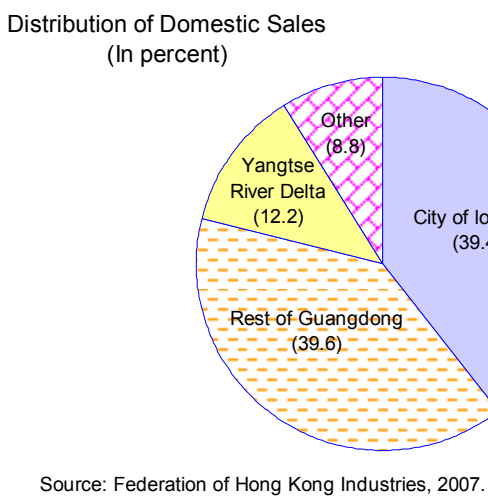

Source: Federation of Hong Kong Industries, 2007 trend, reinforced by China's WTO accession in 2001, that the Mainland as whole has relied less on Hong Kong as an export gate. While total mainland exports to the world nearly quadrupled between 2000-06, Hong Kong's imports from the Mainland only less than doubled. This suggests that relative to the rest of the Mainland, the PRD has become considerably more important for Hong Kong SAR as a market of producer and trade services. Established trade linkages at the firm level of Hong Kong-related companies operating in the PRD have been a key factor for this development (Box 2). It is also noteworthy, that main markets for domestic sales of Hong Kong-related companies are cities in Guangdong province, which accounted for about 70 percent of total domestic sales in 2007, reinforcing the link between Hong Kong SAR's and the PRD's economic cycles, and, ultimately, their dependence on exports to advanced countries.

Bringing connectivity, investment and trade together, Hong Kong-based firms have become global leaders in supply chain management. The example of the Li\&Fung trading company illustrates how improved connectivity and firm-level trade and investment linkages have worked together to produce a leading company in global supply chain management that has been benchmarked in various Harvard Business Case Studies (e.g., O’Connel, 1996). As a supply chain manager the company's success relies on its flexibility in dissecting the 


\section{Box 2. Firm-Level Trade Links Between Hong Kong SAR and the PRD}

Aggregate trade flows between Hong Kong SAR and the PRD are underpinned by decisions at the firm level. According the FHKI survey, 67 percent of all Hong Kong invested enterprises in the PRD exclusively exported their goods through Hong Kong and an average of 44 percent of the exported goods was exported through Hong Kong. On the import side, 70 percent of the enterprises surveyed imported all their raw materials through Hong Kong, and an average of 41 percent of imported materials went through Hong Kong.

\begin{tabular}{|c|c|c|c|}
\hline \multicolumn{4}{|c|}{$\begin{array}{l}\text { Pearl River Delta: Trade Pattern of Hong Kong Firms } \\
\qquad \text { (In percent) }\end{array}$} \\
\hline & $\begin{array}{l}\text { Through } \\
\text { Hong Kong SAR } \\
\text { Only }\end{array}$ & $\begin{array}{l}\text { Through both } \\
\text { Hong Kong SAR } \\
\text { and the Mainland }\end{array}$ & $\begin{array}{l}\text { Through } \\
\text { the Mainland } \\
\text { Only }\end{array}$ \\
\hline Exports & 67.0 & 15.2 & 17.8 \\
\hline Raw material imports & 69.8 & 15.5 & 14.7 \\
\hline
\end{tabular}

The importance of the link between trade and investment is also reflected by the fact that the primary purpose of Hong Kong-related enterprises in the PRD remains exports. Among all enterprises surveyed, 52.4 percent were engaged in export only, 14.1 percent in domestic sale only and 21.5 percent in both businesses. Based on the average value of products, exports, domestic sales and internal transfers accounted for 68 percent, 28 percent and 4 percent, respectively.

\begin{tabular}{|c|c|c|c|c|}
\hline \multicolumn{5}{|c|}{$\begin{array}{l}\text { Pearl River Delta: Distribution of Sales of Hong Kong Firms } \\
\qquad \text { (In percent) }\end{array}$} \\
\hline & \multirow[b]{2}{*}{ All } & \multicolumn{3}{|c|}{ Percentage in Average Value of Product } \\
\hline & & Export & Transfer & Domestic sale \\
\hline \multicolumn{5}{|l|}{ Single role } \\
\hline 100 percent export & 52.4 & 100.0 & 0.0 & 0.0 \\
\hline 100 percent transfer & 0.7 & 0.0 & 100.0 & 0.0 \\
\hline 100 percent domestic sale & 14.1 & 0.0 & 0.0 & 100.0 \\
\hline \multicolumn{5}{|l|}{ Dual roles } \\
\hline Export and transfer & 1.8 & 61.4 & 38.6 & 0.0 \\
\hline Export and domestic sale & 21.5 & 54.4 & 0.0 & 45.6 \\
\hline Transfer and domestic sale & 2.2 & 0.0 & 33.7 & 66.3 \\
\hline \multicolumn{5}{|l|}{ All three roles } \\
\hline Export, transfer and domestic sale & 7.3 & 37.4 & 23.8 & 38.8 \\
\hline Overall Weighted Average & 100.0 & 68.0 & 3.9 & 28.2 \\
\hline
\end{tabular}

Source: Federation of Hong Kong Industries (FHKI; 2007). 
manufacturing process at each step to meet customers' demand in terms of quality, timeliness and price. This flexibility in turn requires that the movements of goods, capital, labor and know-how between the company and its partners, including in the PRD, are frictionless and reliable (Box 3).

\section{Box 3. Hong Kong SAR as a Producer and Trading Services Hub: Li\&Fung Ltd. ${ }^{1 /}$}

Li\&Fung Ltd, amongst the top 20 publicly listed companies in Hong Kong SAR, offers sourcing services mainly to U.S. and European retailers, including retail chains, supermarkets and consumer goods brands. Since its founding in Guangzhou in 1906 and later relocation to Hong Kong, the company has transformed itself from a trading intermediary to a global supply chain manager. In the PRD it has subsidiaries and joint-ventures in Dongguan, Guangzhou, Huizhou, Shenzhen, and Zhongshan. Today, its export trading services cover product design, raw material sourcing, production coordination, logistics, and financing. While its sourcing network extends to all parts of the world, the PRD remains a core area.

As a supply chain manager, the company's success relies on its flexibility in dissecting the

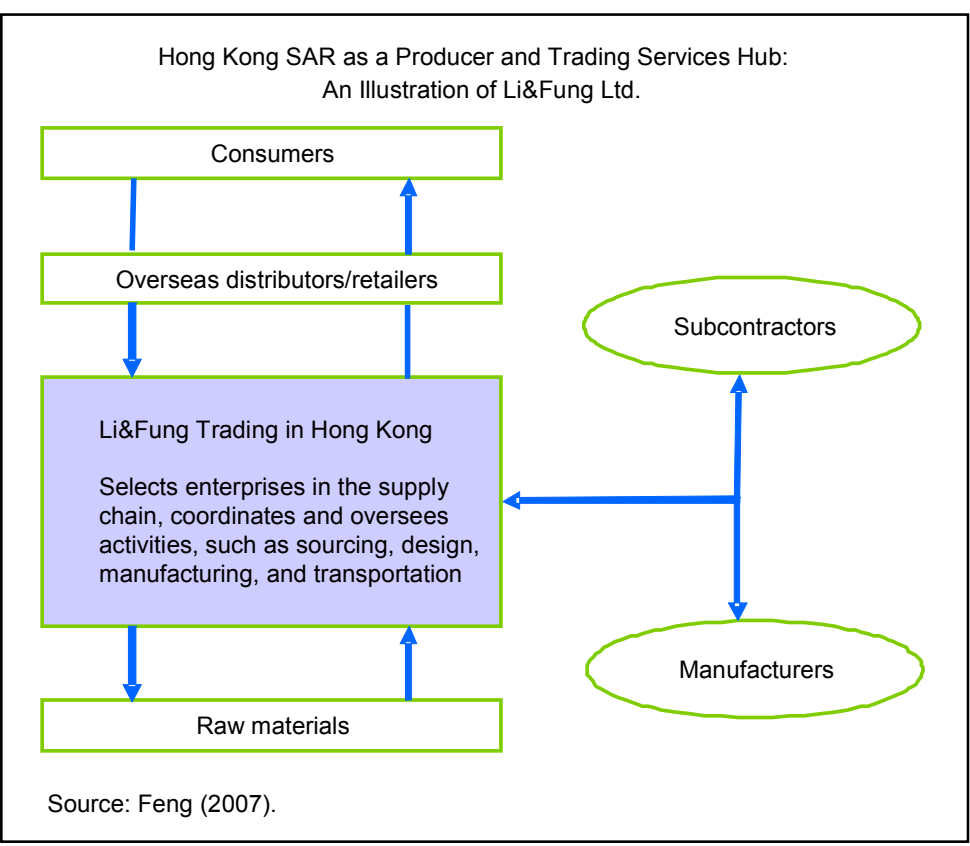
manufacturing process at each step to meet customers' demand in terms of quality, timeliness and price. For example, an order to produce stuffed dolls for a European brand could involve the sourcing of fabrics, their coloring, the stuffing material and so forth from different factories in different countries while final assembly could also be spread across different factories, including in the PRD. The Li\&Fung company would provide the just-in-time logistics and coordination, from design to packaging, to delivery and financing, to ensure that all the dolls arrive on the shelves in Europe at the same time and are perfectly matched as if they came from a singly factory.

1/ Based on material in Feng (2007).

Beyond trade and investment, financial integration is much less advanced, notwithstanding greater services integration under the Closer Economic Partnership Agreement (CEPA). In recent years, the CEPA has played a key role in deepening the investment and trade linkages between Hong Kong SAR and the PRD and streamlining regulations as a basis for a more integrated common market (Box 4). While CEPA has in the first instance helped strengthen Hong Kong SAR's traditional role as a trade and producer services hub, CEPA has also provided momentum for further integration of financial services, which has been lagging so far. Although the number of Mainland listings and their share in market capitalization in the 


\section{Box 4. The Integrative Role of the Closer Economic Partnership Agreement (CEPA)}

The Closer Economic Partnership Agreement (CEPA) of 2003 was the first free trade agreement of Mainland China and set out to boost business confidence in Hong Kong SAR after the SARS crisis by advancing the WTO timetable for Hong Kong SAR companies, liberalizing the individual visit scheme to Hong Kong SAR and ending the quota system for Mainland company listings on the Hong Kong SAR stock exchange. In the course of five supplements signed between 2004 and 2008 the number of tariff free goods has risen to 1,510, while the number of service areas where Hong Kong SAR-based firms enjoy preferential market access has increased to 40 .

While strengthening Hong Kong SAR's traditional role as a trade and producer services hub for the Mainland, CEPA has also become increasingly important for financial services integration.

- Under CEPA Supplement IV, signed in July 2007, access to the Mainland market for Hong Kong SAR banks has been widened, in particular by lowering size requirements relative to WTO commitments (US\$6 billion in assets as opposed to US $\$ 20$ billion).

- Under CEPA the Mainland has been committed to supporting its banks in setting up subsidiary operations in Hong Kong SAR. In this context, the takeover of Wing Lung Bank by Merchants Bank (headquartered in Shenzhen) in 2008 marks an example how banks in the PRD begin to use Hong Kong SAR as a platform to develop their overseas business, and tap expertise in nontraditional areas, such as wealth management.

- Also under CEPA, access for insurance companies has been eased as Hong Kong firms can form groups to fulfill the minimum conditions set out for foreign insurers under WTO commitments, while insurance agency companies can set up wholly-owned subsidiaries on the Mainland.

- Restrictions on Hong Kong SAR securities companies to operate on the Mainland and on qualified Mainland companies to set up subsidiaries in Hong Kong SAR have also been eased.

A number of provisions under CEPA are designed specifically to strengthen financial integration with the PRD.

- Green lanes are set up for fast track approval of applications of Hong Kong SAR banks to open branches in Guangdong, as well as Central, Western and North Eastern areas of the Mainland.

- Under an agreement between Hong Kong SAR's Office of the Commissioner of Insurance (OCI) and the China Insurance Regulatory Commission (CIRC), Hong Kong SAR residents can take the qualifying examinations for insurance intermediaries in Shenzhen, and an examination center was set up in Hong Kong in 2008.

Various studies point to substantial economic benefits for Hong Kong SAR. The Hong Kong SAR government estimates that in the first three years of CEPA implementation 36,000 additional jobs were created in Hong Kong SAR, while the individual visitor's scheme generated more than HK $\$ 7$ billion in annual retail sales (3.6 percent of total) over the period 2004-07. Ching, Hsiao and Wan (2008) estimate that CEPA added an average 2.8 percentage points to real GDP growth in Hong Kong SAR between 2004 and 2007. 
Hong Kong stock exchange has steadily increased in recent years, listings from PRD companies have been relatively rare and sporadic. Estimates indicate that PRD companies only account for 6 percent of Mainland companies' market capitalization in Hong Kong SAR. Under CEPA Supplement IV, there are a number of provisions designed to specifically strengthen Hong Kong SAR's financial linkages with the PRD, including fast track approval for Hong Kong banks to open branches in Guangdong. Shenzhen, the city neighboring Hong Kong is the most financial services intensive in the PRD region. More Hong Kong banks have increased their branch network in the PRD under CEPA. ${ }^{9}$ By way of CEPA, Hong Kong banks were also allowed to conduct renminbi business on the Mainland ahead of the WTO timeline for other foreign banks. Separately, there are other schemes beyond CEPA that serve to facilitate financial links between
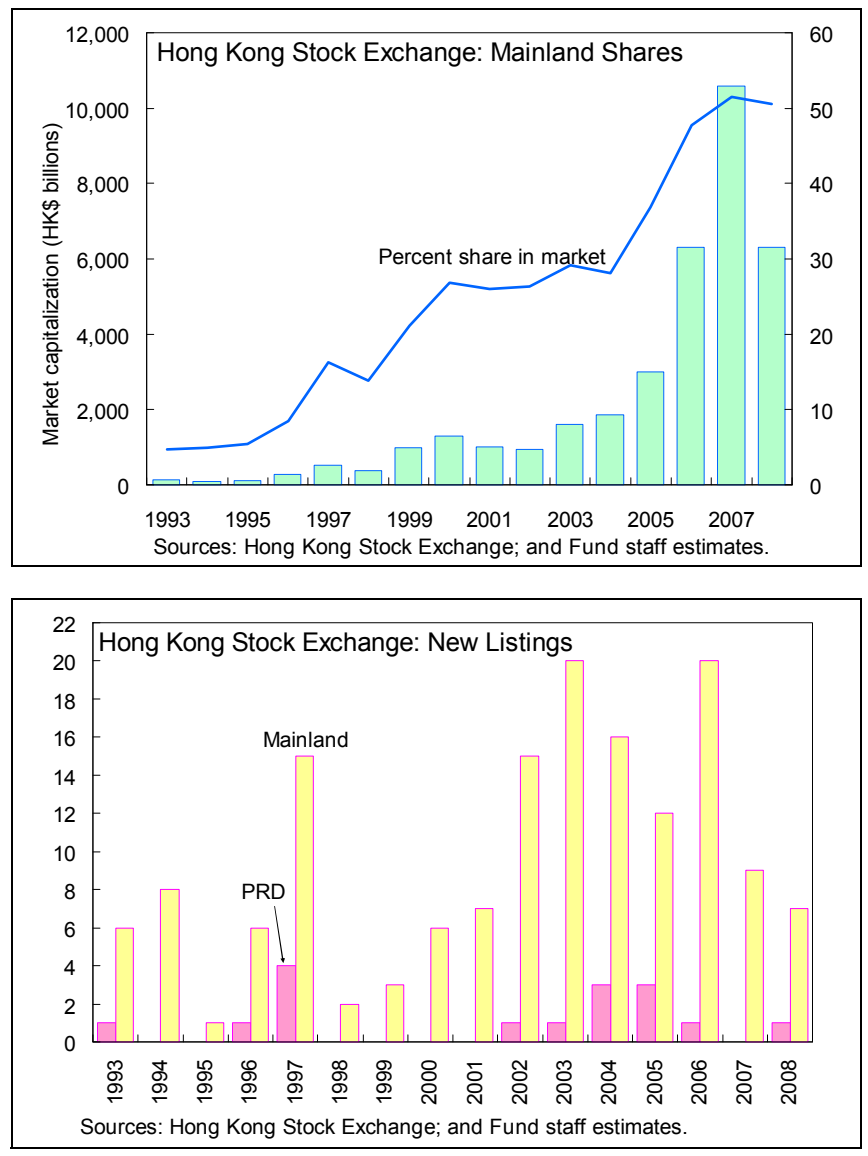

Hong Kong and the Mainland, including the PRD. For instance, since 2004 banks in Hong Kong have been allowed to offer renminbi businesses under clearing arrangements provided by the People's Bank of China. ${ }^{10}$ Regarding activities of PRD banks in Hong Kong, the takeover of Wing Lung Bank by Merchant Bank, which is headquartered in Shenzhen, in 2008 marks the increased interest of regional banks to use Hong Kong as a platform to develop their overseas business and tap expertise in nontraditional areas, such as wealth management, for which demand has been growing rapidly in the PRD.

\section{Employment: The Human Capital Dimension}

The activities in the PRD by Hong Kong enterprises have not only created jobs for Mainland workers, but also contributed significantly to the employment in Hong Kong SAR and crossborder movement of managers and technical staff. The FHKI survey shows that Hong Kong enterprises employ a total of 9.6 million people in the PRD, among which 5.9 million in

\footnotetext{
${ }^{9}$ At end-June 2008, Hong Kong SAR banks were operating 198 branches and sub-branches on the Mainland (either as branches of the Hong Kong entity or as branches of their Mainland subsidiary), as compared to 103 branches and sub-branches at end 2006, representing a 92 percent increase. The number of branches or sub-branches in Guangdong accounts for 32 percent of the total.
}

${ }^{10}$ As of August 2008, there were 40 banks in Hong Kong handling a total of nearly 1.2 million RMB accounts. 
the Eastern PRD, 1.2 million in Guangzhou and about 2.6 million in the Western PRD. Overall, this is equivalent to 40 percent of the workforce in the PRD. Regarding employment effects for Hong Kong, the proportion of Hong Kong SAR residents working in the Mainland has increased from less than 2 percent of total (or some 52,000 ) in 1988 to over $7 \frac{1}{2}$ percent (nearly 240,000) in 2004, with nearly 90 percent estimated to work in Guangdong. Mirroring the more symmetric division of labor within firms between their Hong Kong and PRD locations, in particular in management and administrative activities, about 80 percent of Hong Kong SAR residents working across the border are responsible for managing and supervising the daily operation of a company. ${ }^{11}$ Moreover, the direct and indirect employment effect in Hong Kong SAR by attracting PRD-related producer and trading services is estimated at 1.5 million jobs (40 percent of the labor force). ${ }^{12}$

With increased cross-border movements of managers and technical staff, greater connectivity will also become more important along the employment dimension. Cross-border movement of managers is likely to further increase significantly in the future. According to the FHKI
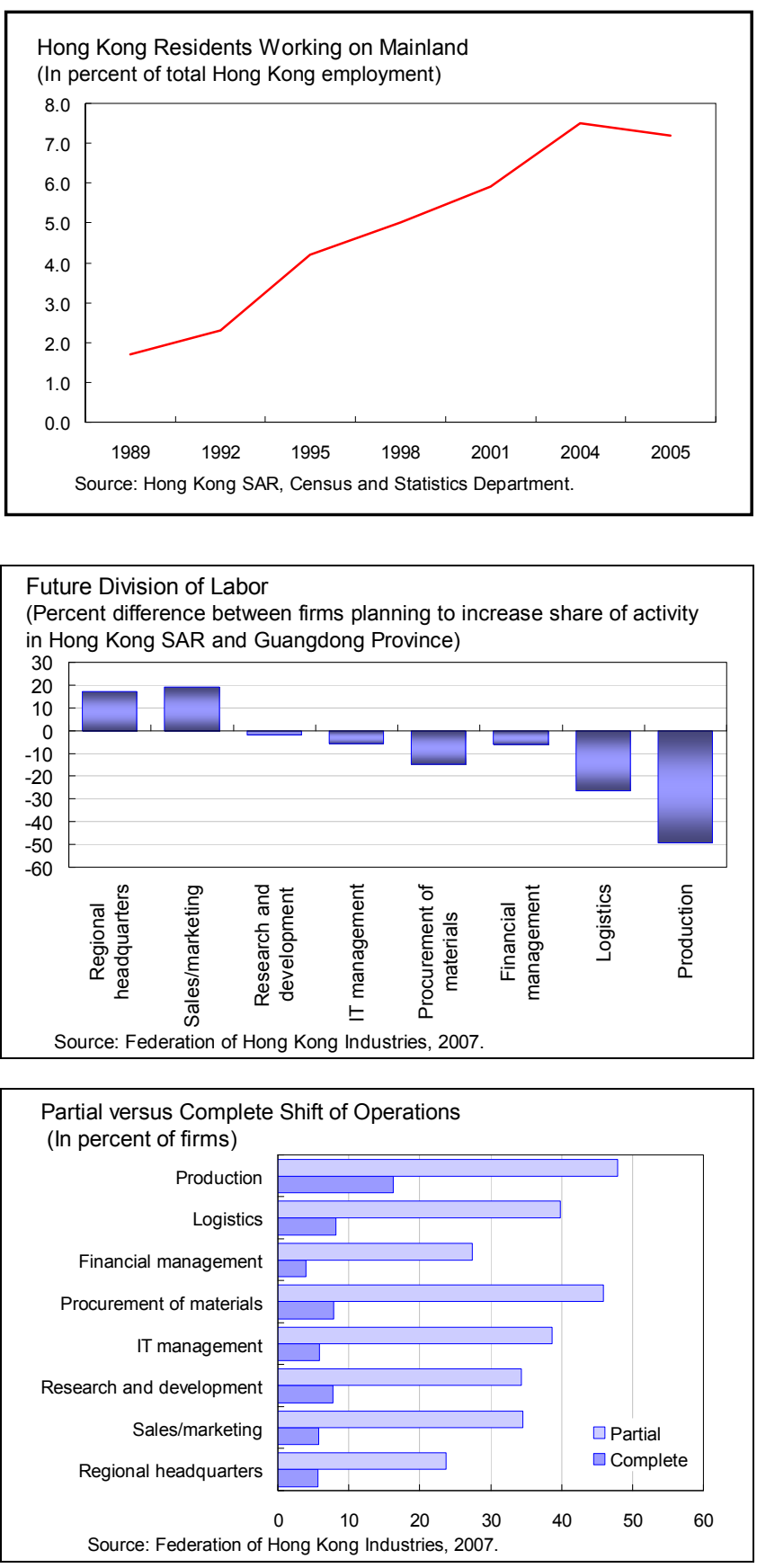

\footnotetext{
${ }^{11}$ See Made in PRD, a report by the Federation of Hong Kong Industries (FHKI), 2007. Statistics on cross-border travel also suggest a sharp rise in the number of commuters, as business trips between Hong Kong SAR and the Mainland by Hong Kong residents increased from 16 million in 2000 to nearly 23 million (or an average of about 440,000 trips per week) five years later.

${ }^{12}$ This estimate includes half a million workers directly employed by Hong Kong companies investing the PRD, and one million in producer services linked to the PRD. It is based on earlier data from Wong, Tao and Chan (2000).
} 
survey, a majority of respondents with operations in both the PRD and Hong Kong SAR considered maintaining offices in Hong Kong for the quality of its business and professional services and other traditional strength such as free flow of information and the legal and tax system. Moreover, surveyed enterprises are not expected to significantly change the division of labor between their Hong Kong and Guangdong operations over the medium term as activities would be expanded according to the two regions' traditional specialization and the share of firm ready to move certain operations entirely into one region would remain a small fraction of the total.

\section{Costs of Integration: The Environmental Dimension}

Rapid industrialization has led to severe environmental problems across the greater PRD, including Hong Kong SAR. Since the early 1970s, the number of hazy days in Hong Kong SAR has risen ten-fold. According to publicly available statistics since 1996, concentration levels of most critical air pollutants, except suspended particulates, have increased significantly, in some cases by 20 percent or more. Air pollution does not stop at the border: month-to-months variations in pollution levels are closely correlated between Hong Kong SAR and the PRD and generally exceed internationally accepted norms in both areas (Figure 5). Geographical data also suggest that pollution levels in Hong Kong

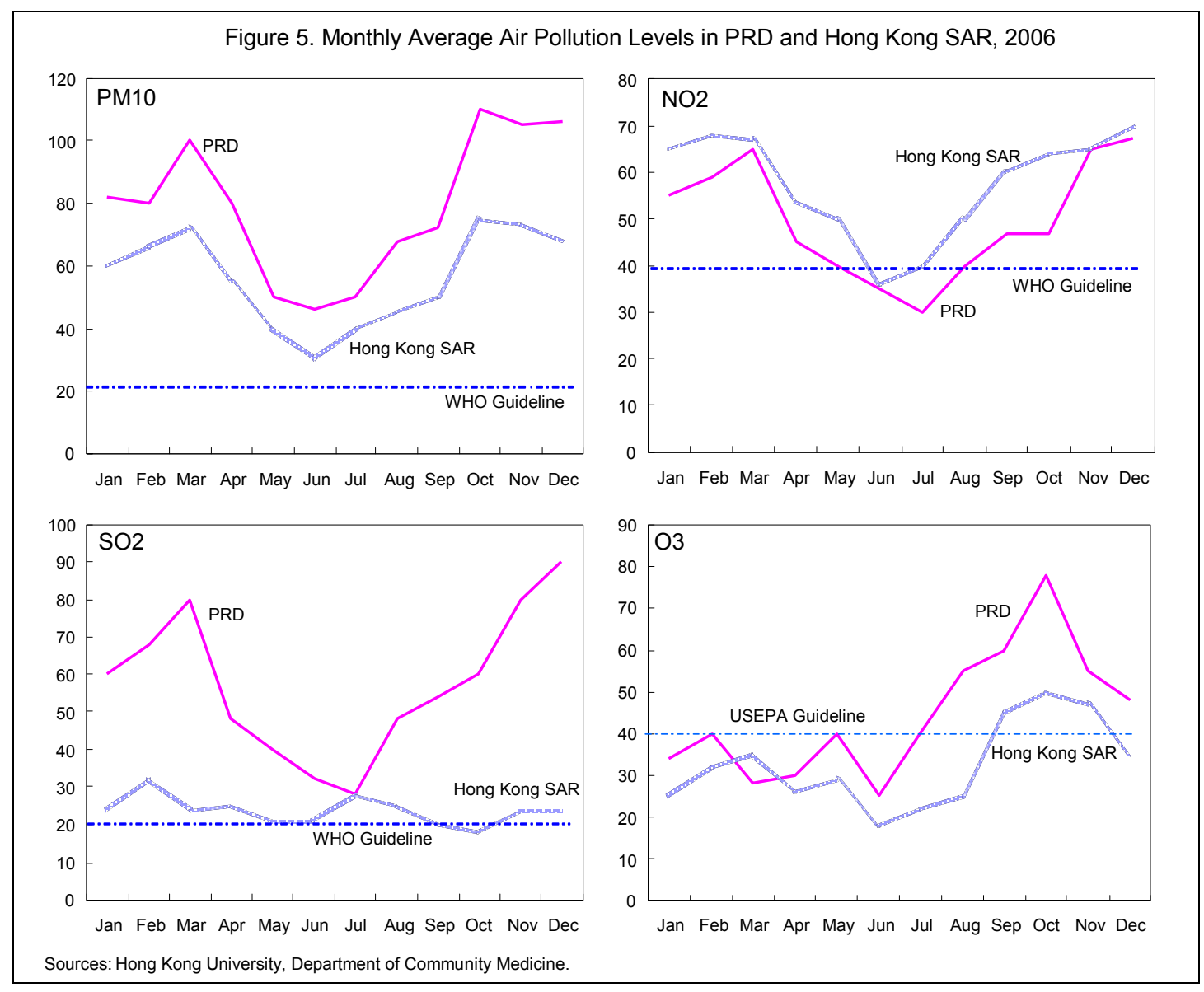


are generally more closely linked with those in neighboring Shenzhen, than with the PRD as a whole. Furthermore, on nearly 40 percent of days in a calendar year Hong Kong SAR's air pollution is predominantly accounted for by sources from the PRD. Yet, a clean environment is a key aspect of Hong Kong SAR's competitiveness as an international financial center, and therefore for the greater PRD as a whole. The availability of skilled labor is often ranked as the most important competitiveness factor in assessing global financial centers, which in turn depends on the quality of life, including a clean environment (Leung and Unteroberdoerster, 2008). Other costs of pollution, such as a deterioration of health indicators and property values should also not be underestimated. ${ }^{13} \mathrm{In}$ this sense, economic integration in the greater PRD, which has been fueled by

Hong Kong SAR's comparative advantage as a services hub, is undermining the basis for future economic gains.
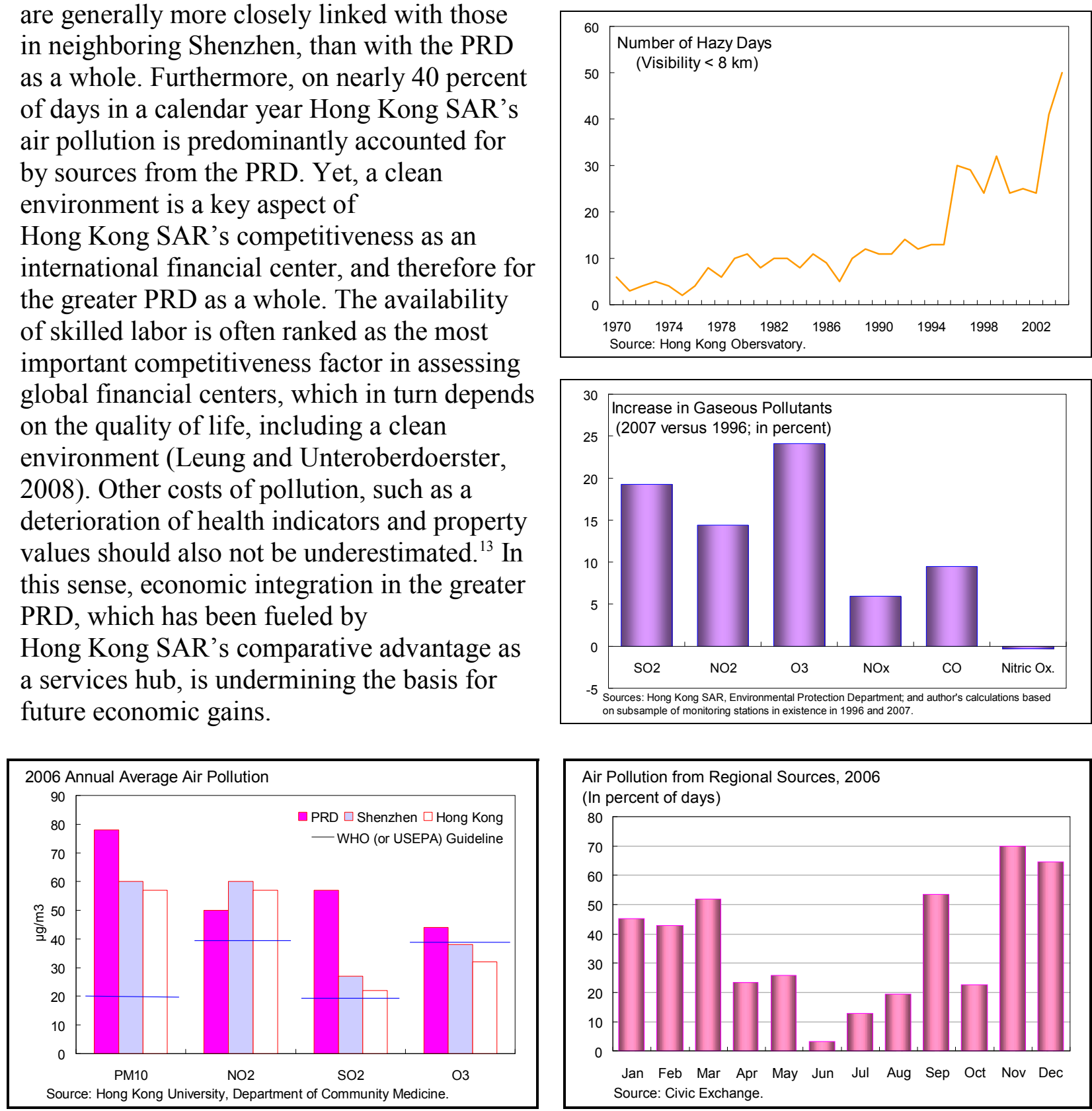

Air Pollution from Regional Sources, 2006 (In percent of days)

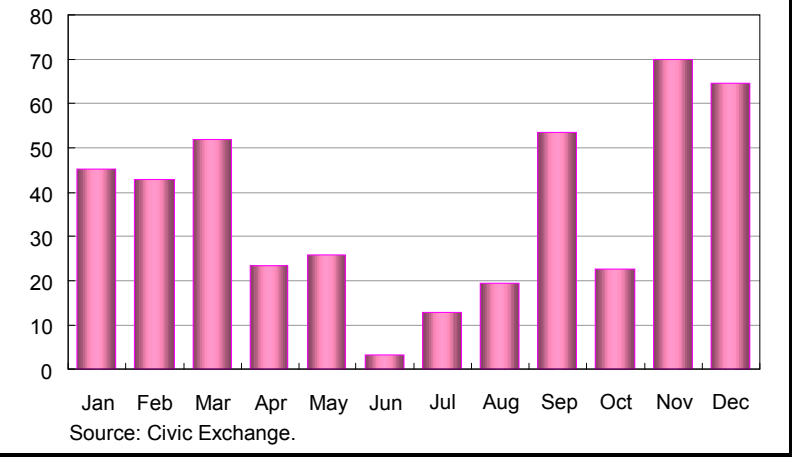
${ }^{13}$ See report by Civic Exchange, A Price too High: The Health Impacts of Air Pollution in Southern
China, 2008. 


\section{OPPORTUNities ANd CHALlENGES}

Hong Kong SAR's role in the integration process has been as an investor and a hub of producer services, supporting the rapid growth of manufacturing in the PRD and linking it to the rest of the world through trade. Integration of financial services has so far played a less prominent role. Further integration and growth in the greater PRD will depend on the continued smooth flows of goods, capital, people, and know-how in the area. However, rapid industrialization has also resulted in severe environmental problems, with the level of air pollution in Hong Kong SAR now considered a threat to its competitiveness as an international financial center. This section concludes by outlining key policy issues from a Hong Kong SAR perspective, to ensure the opportunities from further economic integration are fully seized while the challenges and associated costs are minimized.

\section{Enhancing Connectivity through Infrastructure Improvements}

Connectivity has played an important role in the spread of economic development in the PRD. As highlighted in the previous section, so far foreign direct investment has been concentrated in those areas of the Eastern Pearl River Delta which are closest to Hong Kong SAR. This suggests that improved transport links between Hong Kong SAR and Western cities are critical in tapping the growth potential in relatively underdeveloped areas. The governments on both sides of the border have realized the importance of improving the transportation links between Hong Kong and PRD, and are cooperating to build infrastructure to further improve the transportation efficiency, such as the planned Hong Kong-Macau-Zhuhai bridge. This would create the first land-link between Hong Kong and the western part of PRD, thereby significantly reducing time and cost of transportation.

\section{Harmonizing Policies and Creating a Common Market}

The benefits of greater connectivity through infrastructure will however depend on efforts at harmonizing policies and regulation and thereby creating a common market with a frictionless movement of goods, services, and people. This results from the already high degree of interdependent trade and investment linkages and the sophistication of Hong Kongbased supply chain managers, placing a premium on speed and flexibility. Significant progress has been made to reduce costly frictions in the trade of goods and services. ${ }^{14}$ At the same time, the impact on Hong Kong SAR's processing trade business by recent changes in Mainland policies, notably the reduction of export rebates in 2007 and the tightening of environmental and labor regulations, may highlight both the sensitivity and robustness of economic relations. While according to a November 2007 survey of the Hong Kong Trade and Development Council (HKTDC) about three quarters of enterprises have been affected by the new regulations, including through an increase in the price of raw materials and semi-manufacturers, nearly 80 percent of respondents dismissed the notion of relocating their

\footnotetext{
${ }^{14}$ For example, according to the FHKI survey, the median loss reported by enterprises from delays at customs between Hong Kong SAR and the PRD halved between 2003 and 2007.
} 
production as it would erode their overall competitiveness. ${ }^{15}$ In part this reflects the development of integrated clusters that has characterized much of the industrialization in the PRD. The resulting network externalities tend to offset the competitive disadvantage that regulations may exert on individual firms or factors of production. Nevertheless, greater predictability and coordination in regulations will be important to reduce to perceived risk of disruptions and promote further investment and trade. Moreover, the high degree of intra-firm division of labor documented in the previous section, underscores the importance of further facilitating the smooth flow of labor, in particular management, including by easing visa-restrictions for work-related travel.

Further expanding business opportunities under the CEPA, which has been a framework for coordinating policies, would enhance Hong Kong SAR's role as service provider to the PRD. In particular, the greater PRD could also benefit from further integration with the rest of the Mainland. This could be achieved by allowing outward processing operations in the PRD to expand domestic sales. As the Mainland economy as a whole is striving for more balanced growth and reducing its dependence on exports, the economies of the greater PRD could tap into a vast new market and also reduce their dependency on the advanced economies' cycle that result from the heavy export orientation of Hong Kong enterprises in the PRD described in the previous section. As financial integration between Hong Kong and the PRD is also set to deepen under phase $\mathrm{V}$ of the CEPA, policies that promote a transfer of knowledge to strengthen accounting standards, disclosure, risk management and literacy of financial services amongst the general public will also become more important.

\section{Building an Integrated Skills Base}

As can be seen from the cross-border employment trends, Hong Kong SAR's competitive edge as a hub of producer services in research, marketing and sales, will critically depend on its future skills base. This is particularly important as firms in the PRD move up the value chain, Mainland enterprises themselves are putting greater emphasis on R\&D investments, and foreign firms may find it more attractive to relocate R\&D activities directly on the Mainland. Hong Kong SAR can leverage its unique advantage in the region as an agglomeration of first-rate universities. Attracting more Mainland students would create a virtuous cycle by which highly trained professionals with in-depths knowledge of Hong Kong SAR and the PRD economy help deepen specialization within the region and also attract more multinational companies to set up R\&D activities in the region.

So far, Hong Kong SAR lags significantly behind other comparable economies in the region in terms of international student mobility, suggesting that the potential for Mainland student exchanges is largely underutilized. UNESCO statistics show that the Mainland is an insignificant destination for Hong Kong students abroad. Vice versa, less than 1 percent of Mainland students abroad are estimated to study in Hong Kong SAR. ${ }^{16}$ In part, this reflects

\footnotetext{
${ }^{15}$ See Hong Kong Trade and Development Council, January 2008.

${ }^{16}$ According to the UNESCO 2006 Global Education Digest there were 343,126 Mainland students abroad. At the same time the number of students in Hong Kong SAR from other Asian jurisdictions was only 3,001.
} 
the fact that Hong Kong SAR is generally lagging behind other advanced economies in the Asia Pacific in attracting foreign students. But it also points to the lack of supply of university places offered to students from the Mainland. For example, education grants from the time-limited Mainland student scholarship scheme declined from HK $\$ 40$ million in fiscal year 2002/03 to HK\$5 million for the last remaining cohort benefiting under the scheme in FY 2007/08. Moreover, data from Hong Kong University suggests that demand from fee-paying students from the Mainland by far outstrips supply by a factor of $1: 40 .{ }^{17}$

The government has increased efforts at attracting more international and Mainland students. Non-local student quotas for publicly funded programs have been increased from 4 percent of total students in academic year 2004/05 to 20 percent in 2008/09, and immigration
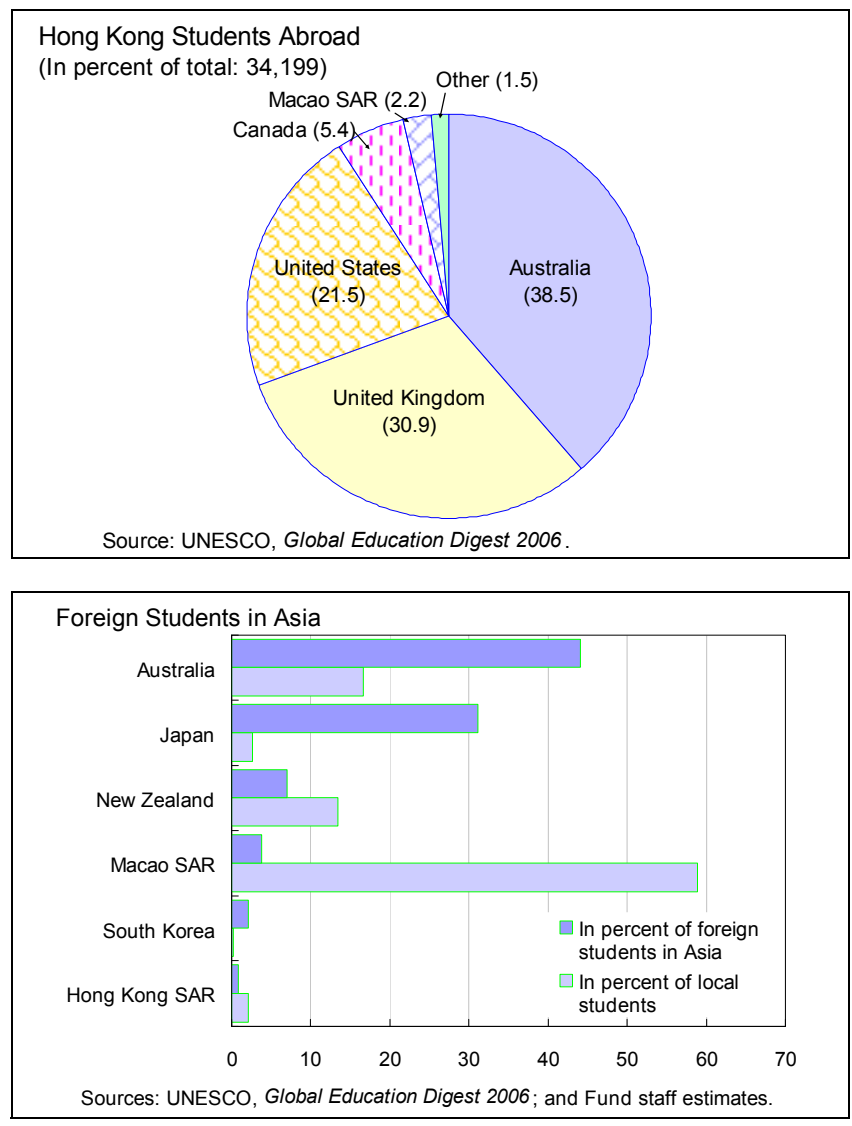
restrictions for non-local students to stay and search work in Hong Kong SAR have been eased. A HK\$1 billion scholarship fund was started in 2008 , which could potentially provide full tuition to about 1,200 local or 600 nonlocal student when fully phased in. Nevertheless, the number of undergraduate students from the Mainland, over 90 percent of all non-local students, has remained small, about 6 percent of total (or less than a third of the quota) in 2008, in part reflecting housing and capacity constraints at universities. Therefore, access for students and technology personnel from the PRD region to Hong Kong -based universities remains limited and should be expanded further, along with more investments to strengthen and expand Hong Kong SAR's tertiary education system.

\section{Tackling Pollution}

Coordinated efforts should be made to reduce pollution and thereby help ensure Hong Kong SAR's status as an international financial center. Besides addressing domestic pollution, Hong Kong SAR should take the lead in tackling regional pollution in the PRD by enacting and enforcing air pollution standards in line with WHO standards. The resulting benefits of reduced cross-border pollution should also be a sufficient incentive for Hong Kong SAR to

\footnotetext{
${ }^{17}$ For the year 2006/07, the Hong Kong University admitted 267 fee-paying Mainland students from a pool of 10,231 applicants.
} 
share the cost of implementing tougher standards in the PRD. This could be done in a framework of greater PRD emission trading, for which the HKEX could be a platform. As standards are raised throughout the greater PRD, guidelines should be clear, predictable, and applicable to all sectors. Sufficient lead-time in introducing new standards can help avoid disruptions, but should not be an excuse for inaction. In any case, as the greater PRD economy moves up the value-added chain to less pollution-intensive activities, the environmental costs of deeper economic integration in the greater PRD may rise at a slower pace.

In fact, efforts at region-wide regulation date as far back as April 2002, when the Hong Kong SAR and Guangdong Province governments agreed on a regional air quality management plan with the aim of reducing regional emissions for four major pollutants (SO2, Nox, RSP and volatile organic compounds) using a 1997 baseline on a "best endeavor basis." However, there is very limited statistical progress towards reducing pollution in Hong Kong SAR (while numbers are not available on the Guangdong side). Against this background, the adoption of the emissions trading pilot scheme (ETPS) for thermal power plants in the PRD region in January 2007 between the Hong Kong SAR Environmental Protection Department (EPD) and the Environmental Protection Bureau (EPB) of the Guangdong Province is a welcome step to further enhance cross-border efforts at tackling pollution. However, further significant efforts are needed in tackling the necessary legal, administrative, and technical infrastructure issues to implement the ETPS. ${ }^{18}$

\section{COnCluding Remarks}

Economic integration with the PRD has played a key role in transforming Hong Kong SAR into a producer services and finance hub and is bound to offer significant future benefits, if properly managed. Judging from past patterns of investment, trade and economic performance, greater connectivity through infrastructure, in particular between Hong Kong SAR and the relatively less advanced Western PRD offers significant growth potential. However, it will need to be accompanied by a frictionless flow of goods, services, people and know-how as modern supply and production networks imply a more broad-based and intensive division of labor between Hong Kong-based firms and their partners in the PRD and place an increasingly high premium on time and flexibility. This calls for greater policy coordination between Hong Kong SAR and the PRD in further promoting trade and investment and in further developing a common human skills base. Policy coordination will also be needed to minimize the costs of integration, in particular rising levels of cross-border pollution which threaten to undermine Hong Kong SAR's international competitiveness as a financial center.

\footnotetext{
${ }^{18}$ For a detailed analysis see Krotman and Malech (2007). Notably, insufficient regulation levels, a lack of enforcement ability on the side of the Guangdong Province government, and the narrow scope of the pilot, suggest that participation and actual reductions in emissions will be limited.
} 
Table 1. Pearl River Delta: Services GDP in 2006

\begin{tabular}{lccrrrr}
\hline & \multirow{2}{*}{$\begin{array}{c}\text { Total } \\
\text { (In percent of GDP) }\end{array}$} & \multicolumn{5}{c}{ In Percent of City's Total } \\
\cline { 3 - 7 } & & Transport & Trade & Finance & Real estate & IT \\
\hline Guangzhou & 35.7 & 30.7 & 27.3 & 10.8 & 19.0 & 12.2 \\
Shenzhen & 34.9 & 12.6 & 27.9 & 23.1 & 27.9 & 8.5 \\
Zhuhai & 26.5 & 16.2 & 41.4 & 9.1 & 20.2 & 13.1 \\
Foshan & 21.9 & 24.4 & 37.8 & 10.0 & 19.7 & 8.1 \\
Huizhou & 20.2 & 19.0 & 42.3 & 6.9 & 22.2 & 9.5 \\
Dongguan & 22.6 & 5.9 & 34.5 & 10.6 & 33.7 & 15.3 \\
Zhongshan & 19.8 & 11.7 & 40.0 & 7.3 & 23.9 & 17.1 \\
Jiangmen & 21.4 & 26.2 & 36.6 & 11.4 & 12.4 & 13.4 \\
Zhaoqing & 23.1 & 14.3 & 52.1 & 4.2 & 17.6 & 11.8 \\
\hline
\end{tabular}

Source: Guangdong Statistical Yearbook 2007. 
Table 2. Pearl River Delta: Main Indicators, 2006

\begin{tabular}{|c|c|c|c|c|c|c|c|c|c|c|c|}
\hline & Guangzhou & Shenzhen & Zhuhai & Foshan & Huizhou & Dongguan & Zhonghan & Jiangmen & Zhaoqing & $\begin{array}{l}\text { Total } \\
\text { PRD }\end{array}$ & $\begin{array}{c}\text { Hong Kong } \\
\text { SAR }\end{array}$ \\
\hline Population (in million) & 9.95 & 7.01 & 1.24 & 5.34 & 3.22 & 6.45 & 2.36 & 3.95 & 3.38 & 42.9 & 6.95 \\
\hline GDP (in billion US\$) & 75.9 & 72.7 & 9.4 & 36.6 & 11.7 & 32.8 & 13.0 & 11.8 & 6.5 & 270.3 & 189.2 \\
\hline GDP per capita & 7,631 & 10,367 & 7,540 & 6,854 & 3,630 & 5,091 & 5,487 & 2,981 & 1,908 & 6,300 & 27,223 \\
\hline Industry (in billion US\$) & 24.6 & 38.6 & 5.2 & 21.8 & 5.1 & 16.5 & 8.7 & 5.5 & 1.4 & 127.4 & 11.0 \\
\hline Industry (in percent of GDP) & 32.4 & 53.1 & 55.5 & 59.6 & 43.2 & 50.2 & 67.2 & 46.6 & 22.1 & 47.1 & 5.8 \\
\hline Exports (in billion US\$) & 32.4 & 136 & 14.8 & 21.1 & 12.3 & 47.4 & 15.6 & 7.4 & 1.8 & 288.8 & 388.8 \\
\hline Exports per capita & 3,256 & 19,401 & 11,935 & 3,951 & 3,820 & 7,349 & 6,610 & 1,873 & 533 & 6,732 & 55,942 \\
\hline Inward FDI (In billion US\$) & 2.9 & 3.3 & 0.8 & 1.1 & 1.0 & 1.8 & 0.7 & 0.7 & 0.7 & 13.0 & 44.4 \\
\hline \multirow[t]{2}{*}{ Inward FDI per capita } & 291 & 471 & 645 & 206 & 311 & 279 & 297 & 177 & 207 & 303 & 6,388 \\
\hline & \multicolumn{11}{|c|}{ (In percent of PRD total) } \\
\hline Population & 23.2 & 16.3 & 2.9 & 12.4 & 7.5 & 15.0 & 5.5 & 9.2 & 7.9 & n.a. & 16.2 \\
\hline GDP & 28.1 & 26.9 & 3.5 & 13.5 & 4.3 & 12.2 & 4.8 & 4.4 & 2.4 & n.a. & 70.0 \\
\hline Industrial output & 19.3 & 30.3 & 4.1 & 17.1 & 4.0 & 12.9 & 6.8 & 4.3 & 1.1 & n.a. & 8.6 \\
\hline Exports & 11.2 & 47.1 & 5.1 & 7.3 & 4.3 & 16.4 & 5.4 & 2.6 & 0.6 & n.a. & 134.6 \\
\hline \multirow[t]{2}{*}{ Inward FDI } & 22.3 & 25.4 & 6.2 & 8.5 & 7.7 & 13.8 & 5.4 & 5.4 & 5.4 & n.a. & 341.5 \\
\hline & \multicolumn{11}{|c|}{ (In percent of PRD average) } \\
\hline GDP per capita & 121.1 & 164.6 & 119.7 & 108.8 & 57.6 & 80.8 & 87.1 & 47.3 & 30.3 & n.a. & 432.1 \\
\hline Exports per capita & 48.4 & 288.2 & 177.3 & 58.7 & 56.7 & 109.2 & 98.2 & 27.8 & 7.9 & n.a. & 831.0 \\
\hline Inward FDI per capita & 96.2 & 155.3 & 212.9 & 68.0 & 102.5 & 92.1 & 97.9 & 58.5 & 68.3 & n.a. & $2,108.2$ \\
\hline
\end{tabular}

Sources: Guandgong Statistical Yearbook 2007; CEIC; and Fund staff estimates. 
Table 3. Foreign Direct Investment (FDI) in Guandong, 1979-2006

\begin{tabular}{lcccc}
\hline & $\begin{array}{c}\text { From } \\
\text { Hong Kong SAR }\end{array}$ & Total FDI & $\begin{array}{c}\text { Share of } \\
\text { Hong Kong SAR } \\
\text { (In percent) }\end{array}$ & $\begin{array}{c}\text { Share of } \\
\text { Guangdong } \\
\text { (In percent of }\end{array}$ \\
FDI in China)
\end{tabular}

Sources: Guandgong Statistical Yearbook 2007; China Statistical Yearbook 2007; and Fund staff estimates.

Table 4. Pearl River Delta: Foreign Direct Investment (FDI), 1996-2006

\begin{tabular}{lccr}
\hline & $\begin{array}{c}\text { Number of } \\
\text { Contracts }\end{array}$ & $\begin{array}{c}\text { Contracted } \\
\text { Value }\end{array}$ & $\begin{array}{c}\text { Utilized } \\
\text { Value }\end{array}$ \\
\hline Eastern & & (In billions of U.S. dollars) \\
Central & 33,816 & 65.3 & 56 \\
Western & 9,737 & 31.2 & 29.6 \\
Total PRD & 19,343 & 47.7 & 40.8 \\
In percent of Guangdong & 62,896 & 144.2 & 126.4 \\
In percent of China & 97.7 & 86.6 & 91.3 \\
\hline
\end{tabular}

Sources: Guangdong Statistical Yearbook 2007; China Statistical Yearbook 2007; CEIC Data Co., Ltd.; and Fund staff estimates. 
Table 5. Choice of Location for Various Business Activities

(In percent)

\begin{tabular}{lcccccccc}
\hline & \multicolumn{3}{c}{2003} & & & 2005 & \\
\cline { 2 - 3 } \cline { 7 - 8 } & HKG & Both & PRD & & HKG & Both & PRD \\
\hline Regional Headquarters & 80 & 11 & 9 & & 66 & 13 & 21 \\
Sales/marketing & 76 & 12 & 12 & & 50 & 19 & 31 \\
Research and Development & 44 & 23 & 33 & & 42 & 33 & 26 \\
IT management & 70 & 18 & 12 & & 39 & 34 & 27 \\
Procurement of materials & 47 & 27 & 26 & & 37 & 26 & 37 \\
Financial management & 87 & 9 & 4 & & 28 & 41 & 31 \\
logistics & 28 & 21 & 51 & & 21 & 34 & 45 \\
Production & 10 & 7 & 83 & & 7 & 16 & 78 \\
\hline
\end{tabular}

Source: Federation of Hong Kong Industries (FHKI; 2003 and 2007) 
Table 6. Role of Hong Kong SAR in Pearl River Delta Export Performance

\begin{tabular}{|c|c|c|c|c|c|c|c|}
\hline & 2000 & 2001 & 2002 & 2003 & 2004 & 2005 & 2006 \\
\hline & \multicolumn{7}{|c|}{ (In billions of U.S. dollars) } \\
\hline PRD exports & 84.8 & 90.8 & 112.6 & 145.1 & 182.4 & 227.3 & 288.7 \\
\hline Guangdong exports & 91.9 & 95.4 & 118.5 & 152.8 & 191.6 & 238.2 & 301.9 \\
\hline Of which: to Hong Kong SAR & 31.5 & 33.7 & 42.4 & 53.9 & 68.6 & 83.7 & 107.2 \\
\hline China exports & 249.1 & 266.1 & 325.7 & 438.3 & 593.4 & 762.5 & 969.7 \\
\hline \multirow[t]{2}{*}{ Hong Kong SAR imports from China } & 91.7 & 87.4 & 91.9 & 100.7 & 117.7 & 134.5 & 152.9 \\
\hline & \multicolumn{7}{|c|}{ (In percent) } \\
\hline Share of PRD exports in Guandong & 92 & 95 & 95 & 95 & 95 & 95 & 96 \\
\hline Share of PRD exports in China & 34 & 34 & 35 & 33 & 31 & 30 & 30 \\
\hline Share of Guangdong in Hong Kong SAR imports from China & 34 & 39 & 46 & 53 & 58 & 62 & 70 \\
\hline Share of Hong Kong SAR in Guangdong exports & 34 & 35 & 36 & 35 & 36 & 35 & 36 \\
\hline
\end{tabular}

Sources: Statistics Yearbooks of Guangdong and PRD Cities, various issues; CEIC Data Co., Ltd.; and Fund staff estimates. 


\section{References}

Ching, Steve, Cheng Hsiao, and Shui Ki Wan, 2008, “A Panel Data Approach for Program Evaluation-Measuring the Benefits of Political and Economic Integration of Hong Kong with Mainland China," mimeo. (Hong Kong: City University of Hong Kong).

Civic Exchange, 2008, A Price too High: The Health Impacts of Air Pollution in Southern China (Hong Kong SAR).

$\longrightarrow$, Beyond the Pearl River Delta: The Contest Begins (Hong Kong SAR).

Enright, Michael and Edith Scott, 2006, "The Greater Pearl River Delta," (Hong Kong: Invest Hong Kong, 2006).

— (Singapore: John Whiley \& Sons).

Federation of Hong Kong Industries, 2007, Made in PRD: Challenges and Opportunities for Hong Kong Industry, (Hong Kong SAR).

Feng, Bang-Yan, 2007, 100 Years of Li\&Fung: Rise from Family Business to Multinational (Singapore: Thomson Asia Ltd).

Hong Kong Trade and Development Council, 2008, "Latest Developments and Strategies of Hong Kong Companies' Processing Trade Business in the Pearl River Delta-Survey Findings," (Hong Kong SAR).

Krotman, Adam and Daniel Malech, 2007, Combating Air Pollution in the PRD: Emissions Trading as a Promising Policy Tool? (Hong Kong SAR: Civic Exchange).

Leung, Cynthia, and Olaf Unteroberdoerster, 2008, "Hong Kong SAR as a Financial Center for Asia: Trends and Implications," IMF Working Paper 08/57 (Washington: International Monetary Fund).

O’Connell, Jamie, 1996, “Li\&Fung (Trading) Limited," Harvard Business Case Studies, 9396-075, June 28.

United Nations Educational, Scientific and Cultural Organization, 2006, Global Education Digest, Comparing Education Statistics Across the World (Montreal, Quebec: UNESCO Institute for Statistics).

Wong, Y.C.R., Z. Tao, and C.S. Chan, 2000, “An Economic Study of Hong Kong's Producer Services Sector and Its Role in Supporting Manufacturing," in Made in PRD: The Changing Face of Hong Kong Manufacturers (Hong Kong: Federation of Hong Kong Industries (FHKI), 2003). 